\title{
Stratigraphy of the White Rock Formation
}

THOMAS E. LANE

Department of Geology, Dalhousie University, Halifax, Nova Scotia

\section{Introduction}

The white Rock and conformably overlying Kentville and Torbrook Formations occupy the cores of regional synclines along the northwestern edge of the Meguma massif (Fig. 1A). These southwestnortheast trending synclines were formed during the Devonian Acadian orogeny, prior to the intrusion of the South Mountain batholith (granite in Fig. 1A) 380 million years ago. This area forms a resistant upland on the south side of a lowland (the Annapolis valley). The lowland is underlain by weakly indurated Triassic sandstones (Fig. 2). Streams flowing northward acorss the geomorphic boundary have incised gorges that expose the Paleozoic stratigraphy of the upland for a distance of $110 \mathrm{~km}$ along the regional strike. The White Rock Formation is also exposed further to the southwest, along Nova Scotia's western coast (Fig. IB).

The White Rock Formation is characterized by thick units of quartz arenites and mafic to felsic volcanic rocks. Crosby (1962) described the formation in the type locality (Fig $3 \mathrm{~A}$, locality 1 ) as consisting of two units of massive quartzite separated by an interval composed predominantly of black slate. These rocks are underlain by slates of the Ordovician Halifax Formation and overlain by slates and siltstones of the Upper Silurian Kentville Formation. In the central Annapolis Valley area (localities 2 to 7), Smitheringale (1973) described these two quartzite units as forming an upper division of the formation; the lower division includes arenaceous strata and a widespread marker unit of volcanic rocks. Farther to the west, at localities 9 and 10, a large volume of volcanic rocks, as well as the distinctive quartz arenites, are included in the formation (Taylor, 1965).

\section{Sedimentary Facies}

The rocks of the White Rock Formation include a wide range of detrital sediments, including shale, mudstone, siltstone, quartz wacke and guartz arenite. volcanic flows and volcaniclastics constitute a minor part of the strata to the east but are major components in the western end of the belt. The facies that characterize the sedimentary rocks of the White Rock Formation may be classified as follows:

Facies 1. Medium- to thick- and evenly-bedded quartz arenites, commonly amalgamated, but interbedded, in places, with thin mudstones. F few associated arenite beds are lenticular. Some of the beds are composed of quartz wacke and/or siltstone (Fig. 19). Parallel-lamination is the prevalent internal structure (Figs. 19, 22, 27, 28 ), in some cases associated with cross-lamination (Figs. 25, 26).

Facies 2. Thin, evenly-bedded siltstones and very fine-grained arenites interbedded with mudstones. The siltstones and mudstones are composed of alternating, even, thin laminae of silt and mud. The laminae commonly are disxupted or obliterated by bioturbation. Subsidiary, medium- to thick-bedded lenticular arenites typically have parallellamination (Figs. 14, 16, 18 20).

Facies 3. Very thin, even beds and laminae of muddy siltstone and mudstone alternating with lenticular, thin beds of very fine-grained arenite. The muddy siltstones are composed of alterrating, thin, mud-rich and silt-rich laminae, the latter commonly being lenticular. Layers of laminated mudstone occur between the siltstones and arenites. The lenticular arenites commonly exhibit cross-laminated ripple-trains (Figs. 12, $13,1524)$.

Facies $4 a$. Lenticular and laminated silty shale, composed of very small-scale lenses of siltstone alternating with thin laminae of mudstone.

Slightly larger lenses of very fine-grained arenite with internal cross-laminae are interlayered with some of these shales (Fig. 17).

Facies 4b. Laminite shales, composed of even laminae of mudstone and claystone and containing interlaminae of siltstone (less than $1 \mathrm{~mm}$ to $1 \mathrm{~cm}$ thick) (Fig. 21).

Facies 4c. Homogeneous shale, generally dark grey to black in colour, bioturbated and locally containing laminae of siltstone.

Facies 4d. Mudstones locally stained red, bioturbated and containing minor interlaminae of siltstone and arenite, found in a few transitional zones between Facies 2 and $4 \mathrm{~b}$.

\section{Stratigraphy}

The stratigraphy of the White Rock Formation is depicted in Figure 4, and the locations of most of the principal sections are indicated in Figure 3A. The description of the stratigraphy given below is based primarily on the outcrops exposed at localities 2 to 7 and at intervening sections (not indicated in Figs. $3 A$ and 4 ). Good stratigraphic control is provided in this area by detailed lithostratigraphic correlations between eleven closely spaced sections (localities 2 to 7 and intervening sections), by the presence of volcanic marker beds, and by well-dated, fossiliferous slates immediately overlying and immediately underlying the White Rock strata.

Uppermost Halifax Formation. The upper portion of the Halifax Formation in the Annapolis valley area is composed of dark grey to buff (occasionally red) silty slate, characteristic of Facies $4 a$. P. current-formed macrostructure of fine-scale (some cross-laminated) siltstone lenses is common to this facies (Fig. 17). To the south and west (localities 9 and 10), black slates (Facies 4c) and grey slate laminites (Facies $4 b$ ) occur in the upper Halifax Formation.

The strata that make up the upper $100 \mathrm{~m}$, approximately, of the Halifax Formation in the 


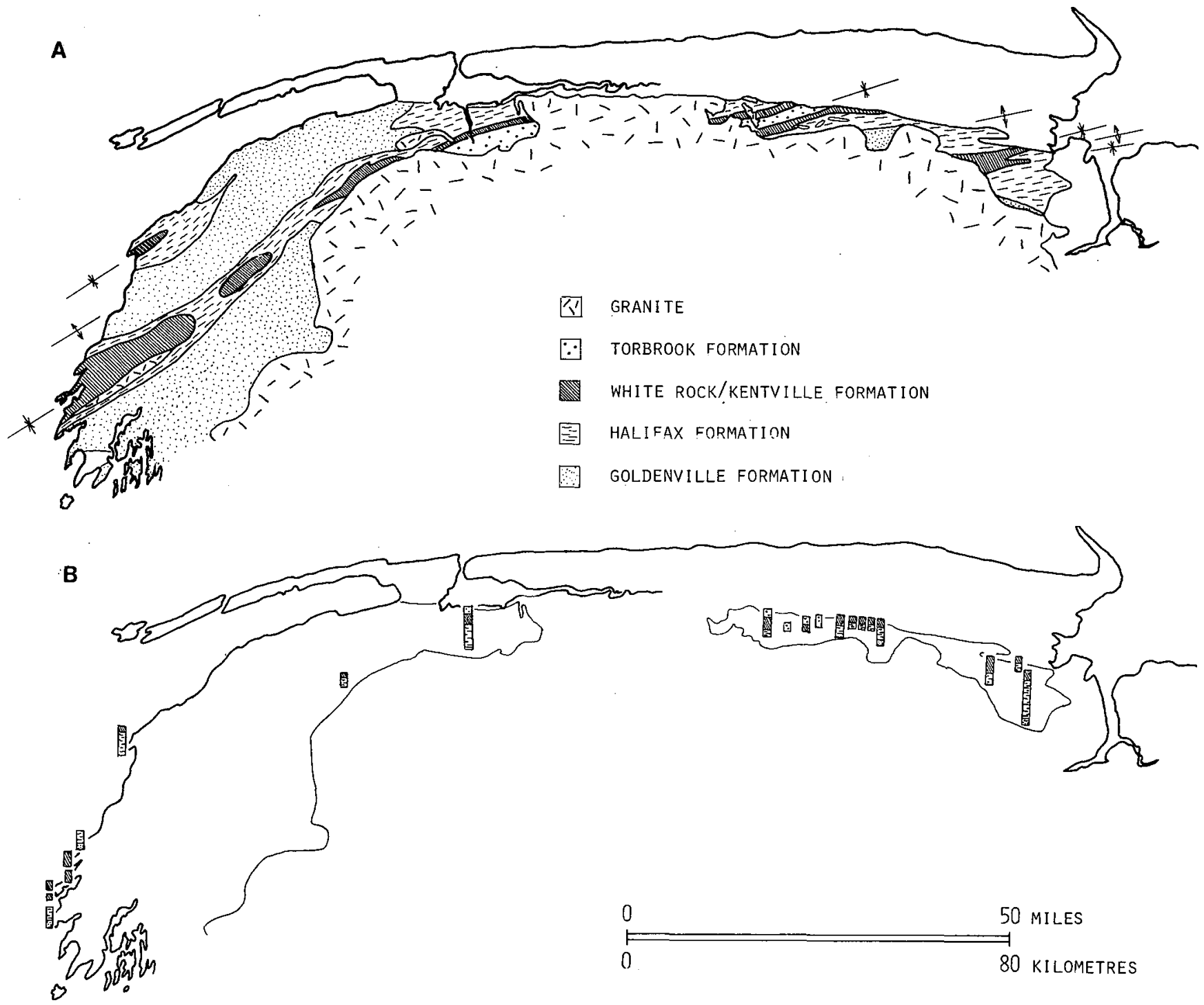

Fig. 1 (a) Paleozoic rocks of southwestern Nova Scotia.

(b) Stratigraphic columns of Middle Paleozoic sections in southwestern Nova Scotia.

Annapolis valley area are distinctive. The facies $(4 a, 4 b)$ represented in this interval are distinguished by the following: (1) abundant carbonaceous shale laminae, (2) common bioturbation, (3) the lack of current-formed, cross-laminated, fine-scale lenses, (4) an unusual laminite subfacies of alternating layers of pure, micaceous siltstone and coarse, quartzose siltstone, and (5) an association with scattered occurrences of unusual paraconglomerates (see below).
The paraconglomerates are limited to several, stratigraphic horizons at Cape st. Mary (locality 10), where they have been described by Taylor (1965, 1969) and Schenk (1972), and to a narrow stratigraphic interval at Kentville (locality 1). The conglomerates are composed of polymictic cobbles and pebbles of quartzite, black slate, laminated siltstone, and rhyolite. The clasts are commonly angular and sometimes faceted. The supporting matrix is a fine-grained, silt-rich. 


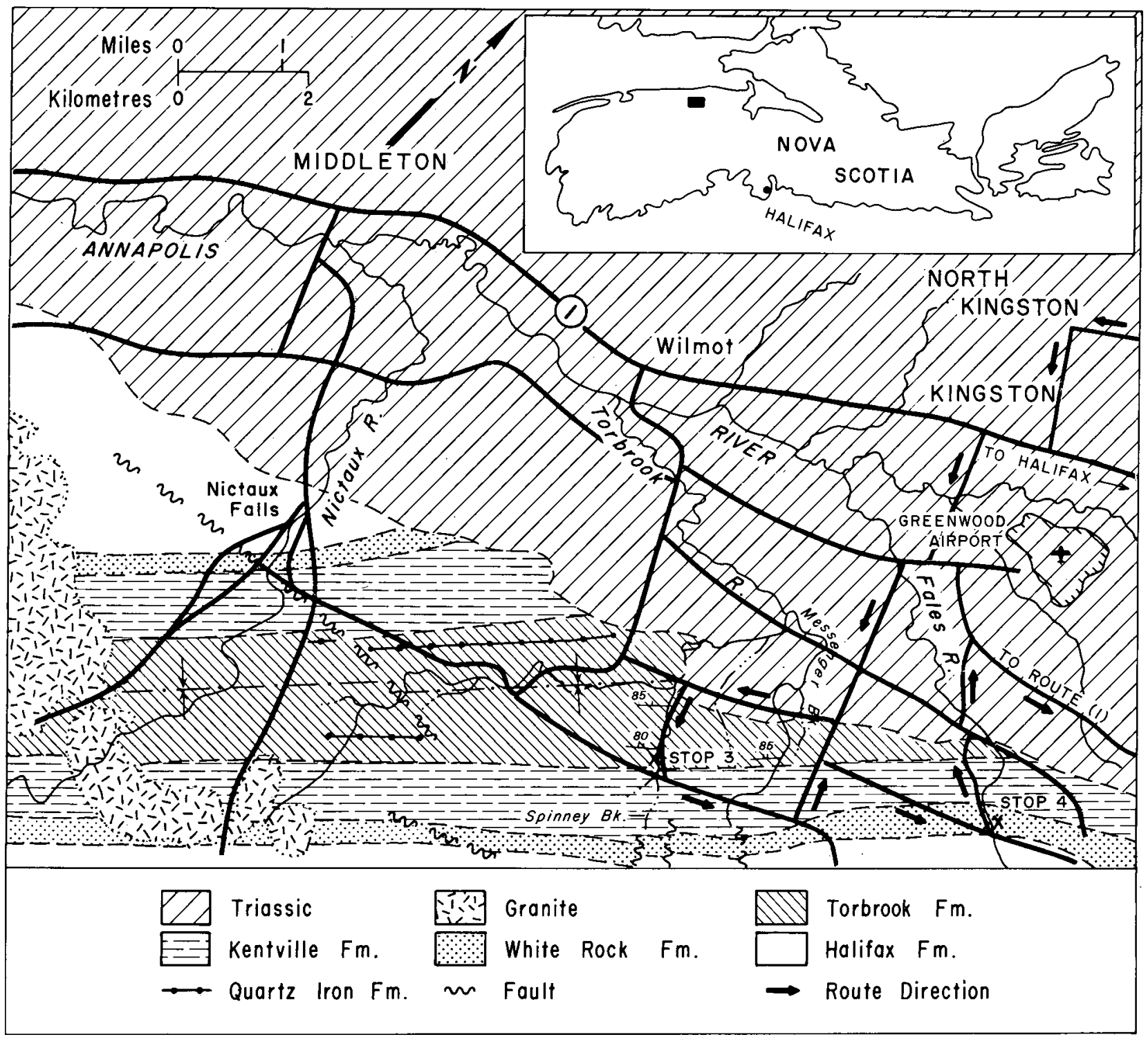

Fig. 2 Geologic map of central Annapolis Valley area, showing locations of Stops 3 and 4. Arrows indicate excursion route.

mudstone. This lithology is comparable to that of glacio-marine diamictites in other areas (Schenk, 1972; Harland, 1974). At Kentville, the paraconglomerates are in transitional contact with the underlying strata, but at Cape St. Mary they may occur above. one or more local unconformities.

White Rock Formation. In the Annapolis Valley area, the White Rock Formation is divisible into two members. The lower member ( 50 to $300 \mathrm{~m}$ thick) is composed of a laterally variable complex of arenites, siltstones, and shales. The base of the lower member is defined by a laterally extensive felsic volcanic unit at some localities and by arenite at others. The upper member $(40$ to $200 \mathrm{~m}$ thick) consists of two, distinctive, massive, quartzite units separated by an intervening shale unit (Fig. 4).

Lower Member. The sedimentary rocks of the lower member are of Facies $1,2,3$ and $4 \mathrm{~d}$. These facies are laterally and vertically transitional with respect to one another (Fig. 4). The vertical transition between the slates and the arenaceous facies is gradational and diachronous with respect to the volcanic marker unit (Fig. 4). The volcanic rocks at the base of the member are composed of a distinctive bimodal sequence of alkali-rich dacites and rhyolites overlain locally by basalts. The felsic rocks, which commonly overlie shale (Facies 4d), occur as massive outcrops of devitrified, ashflow tuffs ( 3 to $50 \mathrm{~m}$ thick) that vary laterally to water-laid, bedded tuffs. The basalts occur as pillow lavas and water-laid, mafic tuffs.

Upper Member. The stratigraphic succession of the upper member is represented at a number of sections (Fig. 4), and is composed of two sharply bounded quartz arenite units (Facies 1) separated by dark laminite shales (Facies 4d). The quartz arenites appear regionally as two extensive sheets, each of variable thickness (10 to $40 \mathrm{~m}$ ). The upper sheet-arenite is the most widespread of the two (Fig. 4). In areas where the sheet-arenites do not appear (Fig. 4), arenaceous sediments of Facies 2 and 3 occur in their place. 
FACIES

DISTRIBUTION

\section{WHITE ROCK}

FORMATION

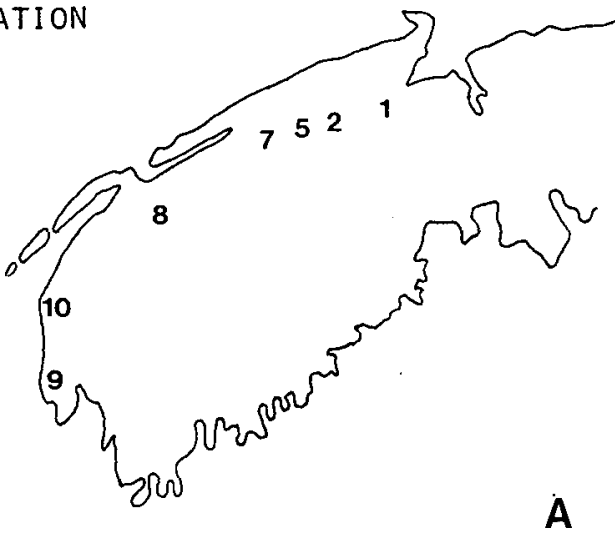

\section{PALEOCURRENT DIRECTIONS}

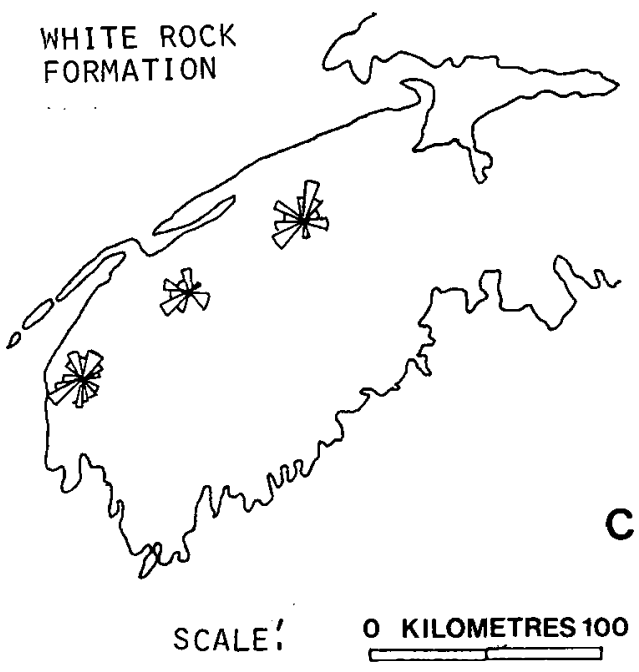

\section{GEOLOGIC DISTRIBUTION}

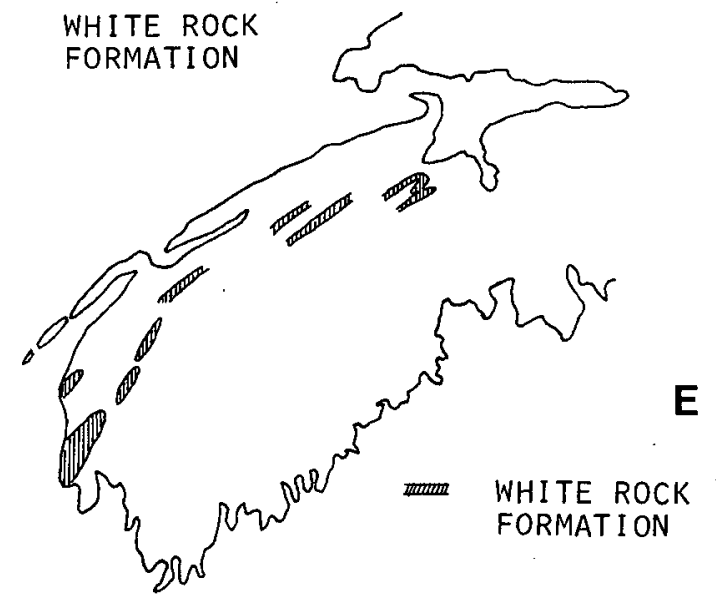

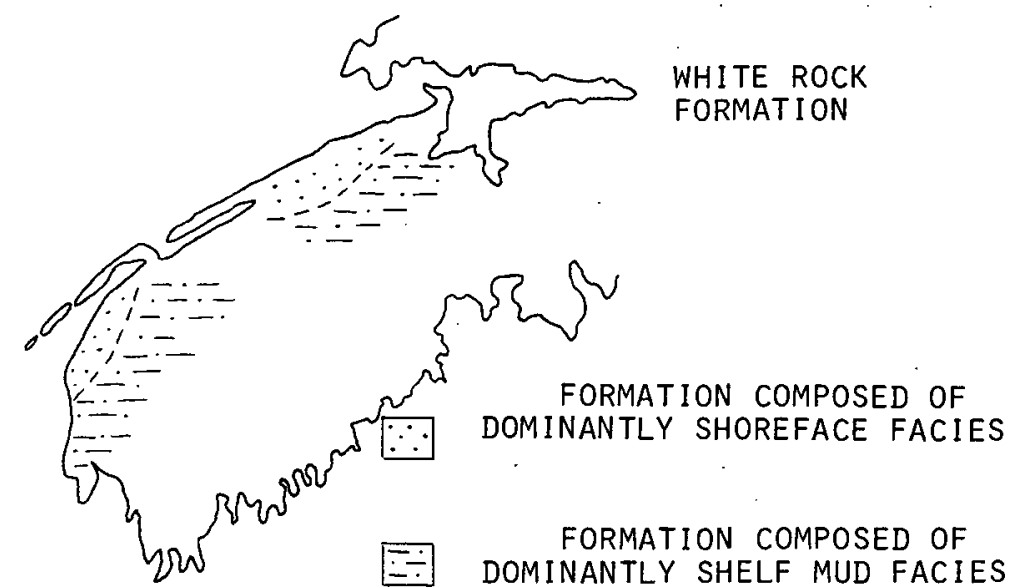

B

\section{MAJOR CURRENTS}

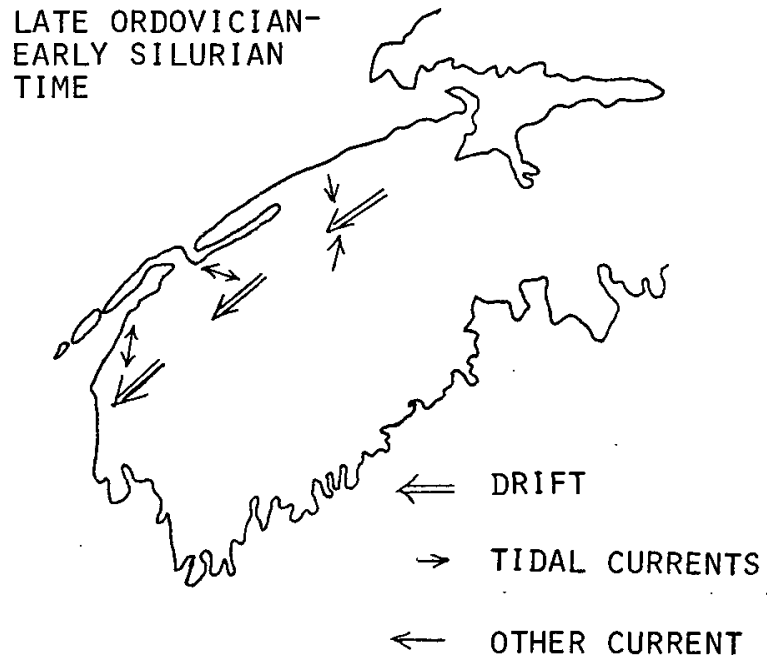

D

Fig. 3 (a) Localities of stratigraphic sections shown in Fig. 4.

(b) Overall distribution of shoreface and shelf facies in the White Rock Formation.

(c) Rose diagrams of paleocurrent directions, White Rock Formation.

(d) Directions of major marine currents during deposition of the White Rock Formation, as interpreted from paleocurrent data.

(e) Outcrop area of the White Rock Formation. 
The sheet-arenites commonly are homogenous, evenly bedded, and relatively fine-grained, but locally the beds exhibit a vertical variation of internal form and composition. These variations occur chiefly in the form of (1) a coarsening upwards in grain size, and (2) a transition upwards from beds with current-formed cross-lamination at their base, to beds with parallel-lamination at their base and wave-ripples and wave-formed corss-lamination at their top.

The sheet-arenites are recognized as the coarsergrained members of two sedimentary cycles that are repeatedly exposed throughout the outcrop area. The sheet-arenites typically lie abruptly on shales or siltstones. Thin successions of siltstones and intercalated, thin-bedded, fine-grained arenites lie immediately on top of the sheet-arenites. The siltstones grade rapidly upwards into black shale laminites with a minor silt content. This finingupwards transition occurs in the lowex part of the upper member and at the contact with the overlying Kentville Formation.

The shales that occur in an intermediate position between these cycles tend to coarsen upwards, accompanied by an upwards increase in the thickness and abundance of siltstone intercalations. The coarsening-upwards succession observed here differs from cycles associated with deltas, where the transition upwards from shales to sandstones tends to be gradual (Selley, 1970). In the white Rock Formation, the transition to the overlying arenites is sharp, not gradational.

The sheet-arenite to shale sedimentary cycles of the upper member are distinctive stratioraphic units that are traceable throughout the outcrop belt. A felsic tuff just above the upper sheet-arenite is laterally traceable for $40 \mathrm{~km}$ and. provides an indication that the sheet-arenites probably are time-stratigraphic units.

Overlying Strata. In the Annapolis valley area the upper member is extensively overlain by the shales of the Kentville Formation (Fig. 4, localities 1 to 8 ). However, in the more highly metamorphosed terrain at the western end of the outcrop belt (localities 9 and 10), an undated succession of siltstones and shales and a very thick group of volcanics (1000 to $2000 \mathrm{~m}$ ) overlies the upper member. Greenstones and amphibole gneisses (metamorphosed products of mafic volcanic flows and pyroclastics), lesser amounts of trachytic prophyries, and interstratified paraconglomerates are the main rock types within this volcanic succession. Taylor (1965) included these volcanic and associated rocks in the White Rock Formation. Their stratigraphic position above the sheet-arenites suggests that they are time-equivalent to the Kentville Formation in the Annapolis Valley area.

\section{Age}

The only fossil found within the white Rock Formation of known age range is a castellate rhynconellid brachiopod from the upper member at locality 9 (Fig. 3A). Its maximum age is Caradocian, but its probable age is younger (Boucot, personal communi= cation, 1971).
Tremodocian graptolites (Dictyonema flabelliforme) and chitinozoans have been found in the Halifax Formation near locality 1 (Fig. 3A), 1000 to $2500 \mathrm{~m}$ below the contact with the White Rock Formation. The Kentville Formation contains several occurrences of Upper Silurian fauna. Graptolites (of the Monograptus nilssoni zone) and conodonts found near the base of the Kentville Formation are lower Ludlovian in age. This evidence indicates that the White Rock Formation was deposited sometime between the Middle Ordovician and Upper Silurian.

The "dropstone" paraconglomerates in the uppermost Halifax Formation may be correlative with tillites of the Ashgillian (Late Ordovician) glaciation in northwestern Africa and western Europe. The two sheet-arenite units of the White Rock Formation may correlate with well-known sheet sands of lower Llandovery and Wenlock ages in various areas of the world.

\section{Depositional Environment}

The strata of the White Rock Formation are mostly marine in origin. Transported shells of marine brachiopods, gastropods, pelecypods, and crinoids, though sparse in occurrence, are found within some siltstones and arenites. Tracks and burrows of organisms characteristic of marine facies in other areas (chondrites, Cruziana and zoophycus) are common to the shales, siltstones and muddy arenites.

Besides the occurrences of the shelly fauna, various depositional characteristics of the rocks indicate that many of the strata accumulated in a shallow marine setting. In situ phosphate nodules in black shales suggest deposition in depths of water less than $200 \mathrm{~m}$ (the maximum depth of presentday phosphate precipitation). Precipitated carbonates (pisolites and algal oncolites) associated with volcanic tuff beds at the formation's base probably formed in marine waters less than 20 metres deep.

The volcanic rocks of the formation are primarily subaqueous in origin, as indicated by pillow basalts, vesiculated and accretionary lapilli tuffs, and basaltic pyroclastics without interstratified flows. Some of the volcanic rocks, however, have features that suggest subaerial conditions of deposition, such as ash flows with flow banding and eutaxitic structures, and mafic flows with weathered tops. The subaerial features probably represent periods of temporary emergence during deposition of the succession.

The types of sedimentary facies observed are consistent with the depositional characteristics noted above, and these facies are analogous to those of the Holocene shallow-marine, shoreface to offshore model described by Lane (this volume). Facies 4 corresponds to the offshore muds, Facies 2 and 3 to the transition zone and lower shoreface sediments, and Facies 1 to the shoreface deposits. The finegrained, distal sediments of Facies 4 are predominant in sections to the south and west, while relatively proximal sandy sediments of Facies 1 are 


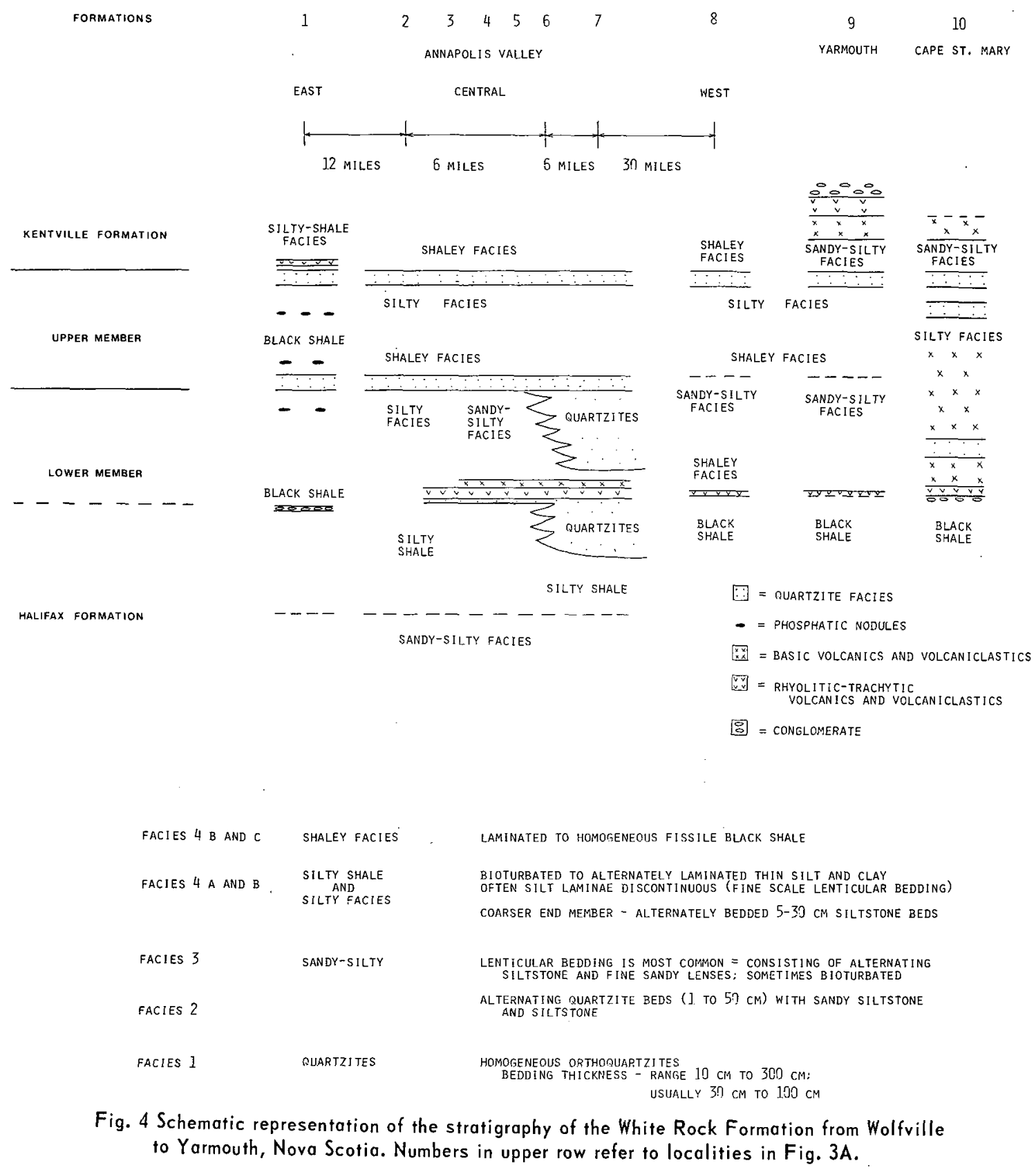

common in the north near the paleoshoreline (see Fig. 3B).

Considered collectively, these facies consist of unbioturbated beds of arenite with sharp upper and lower contacts, alternating with thoroughly bioturbated shales and siltstones. Some of the arenites occur as amalgamated beds. Most of them have flat to gently inclined sets of parallellaminae (Figs. 16, 19, 25, 28). A1so present are scattered trough and planar cross-sets of ripple, mega-ripple and sand-wave bedding forms (Figs. 14 and 26), along with wave-formed straight-crested ripples and cross-laminae (Fig. 15).
The arenites are considered to have been rapidly deposited on a substrate of otherwise slowly accumulating silt and mud. Presumably, the arenites accumulated during periods of high energy, when waves and currents were capable of winnowing and transporting such sediments. The parallellaminated quartz arenites observed in the White Rock Formation are similar to analogues from the present (Lane, this volume), and were carried offshore from beach complexes.

Paleocurrent trends have been determined approximately from studies of ripple marks and cross-stratification in the arenites (Fig. 3C). 
LITHOLOGY

Black Shale

(Kentville Formation)

Sheet-Arenite

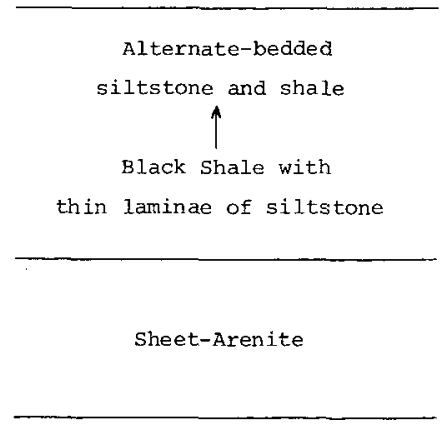

Upward increase in the proportion of sandstone

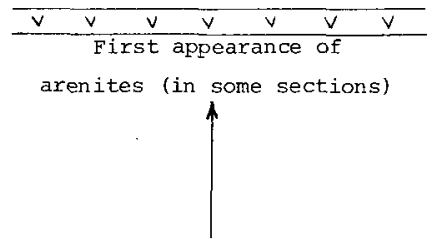

Laminated and bioturbated silty shaley

Very silty shale (with siltstone and sandstones lenses)

(Halifax Formation)
NATURE OF DEPOSITION

Transgression, resulting in relatively deep water and

reduced sediment supply

Reworking and deposition

of shoreface sands

(Shore erosion at initial transgression)

Regression
(coarsening upwards)
Continued transgression, resulting
in relatively deep water and
reduced sediment supply
Reworking and deposition
of shoreface sands
(Shore erosion at initial transgression)

Shore zone progradation

and

Increased effect of storms

Shor: volcanic episode

Continued Regression

Shoreline and shoreface established locally, $\uparrow$

Regression by sedimentation

Regression of the sea, accompanied

by a reduction in the supply

of sediment

Deep water regime

(current activity)

Fig. 5 Sequence of events during deposition of the White Rock Formation and immediately overlying and underlying sedimentary strata.

The paleocurrent directions are polymodal, characteristic of shallow marine deposits. However, a dominant current direction subparaliel to the northeast-southwest regional strike is the product of a dominant offshore current which paralleled the paleoshoreline (Figs. 3C, 3D). Secondaxy bimodal vectors reflect tidal currents that occurred normal to the shore (Fig. 3D).

\section{Glacio-Eustatic Effects}

The Uppex Ordovician (Ashgill) was a time of major continental glaciation in northwestern Afxica, western Europe and South America, and was preceded and followed by major eustatic sea level changes (Termier and Termier, 1952; Beuf et al, 1971; Berry and Boucot, 1973; and Harland, 1974). The Upper Ordovician to Silurian sediments of the White Rock Formation undoubtedly were affected by these events.
Both the distinctive slates of the uppermost $100 \mathrm{~m}$ of the Halifax Formation and those of the lower member of the White Rock Formation are interpreted to represent deposition contemporaneous with glaciation (i.e., low sea-level stands). The presence of dropstones within the strata in the vicinity of the Halifax-White Rock contact is primary evidence for the presence of ice in the region at this time. Carbonate algal oncolites and vitreous ash flows interbedded in the slates indicate shallow-vater and possibly subaerial conditions. The claystone-siltstone laminites found locally within the uppermost Halifax slates were deposited under unique conditions. These alternating strata reflect periodic variations in the supply of relatively coarse-crained sediment. Unusual seasonal changes, such as the formation of shelf ice in or near the region, are a possible cause. 
At a later stage, the arenaceous facies of the lower member was deposited. The arenites probably appeared as a result of an increased supply of quartz sand from the source region (possibly transported in part by glaciers and glacial melt-ivater) and a general shoaling that formed a supra-wave base regime. The climatic changes that initiated deglaciation and possibly increased the intensity of storms in the region could have further increased the supply of coarse sediment.

The strata of the upper member are interpreted as representing sedimentation after glaciation. The sheet-arenites are shallow marine deposits, and the overlying finer-grained sediments were deposited in deeper water (below wave base) clue to transgression of the sea. In particular, the rapid transition from the sheet-arenites to finegrained rocks below and the somewhat gradational transition to fine-grained strata above suggest that the arenites represent sudden and extensive influxes of sand. These influxes probably appeared immediately preceding or during the initial transgression of the sea. Sheet-like sand bodies 10 to $30 \mathrm{~m}$ thick are commonly found on present continental shelves as relics of the Holocene postglacial transgression. Cores taken in these sands commonly contain parallel-lamination of a type that is typically associated with a lower shoreface environment of deposition (e.g. Sanders and Kumar, 1975). The sheet-arenites of the White Rock Formation have these general characteristics.

Bruun's (1962) model for the process of coastal retreat during marine transgression explains the origin of the Holocene sands referred to above, and presumably also the sheet-arenites of the White Rock Formation. He noted that as sea level rises and the sea trangresses landward, the coast retreats by erosional backcutting of the unconsolidated sediments that form the shore profile above the lower shoreface (Fig. $(B)$ ). The eroded material is redeposited during high-energy events in the lower shoreface and further out to sea. Schwartz (1968) applied this model to the Holocene transgression in various areas, showing that sand-sheets 20 to 30 $m$ thick were deposited across inner shelves as the sea level rose. These thicknesses are comparable with those of the sheet-arenites of the White Rock Formation.

This model has been developed to explain the origin of Holocene sheet sands, which unconformably overlie terrestrial strata. The model may be extended to explain sheet-arenites which conformably overlie marine facies, as in the case of the White Rock Formation (Fig. 6A). The common association of these types of arenites at the base of marine transgressive successions marks the brief transitional period characteristic of initially transgressing seas, when high-relief, shoreline sediment bodies (constructed in dynamic equilibrium with a stable sea level) are bevelled. During this time backcutting of the shore zone is pronounced, and large amounts of fine sand, silt and mud are released to the lower shoreface and offshore zones. The sea floor in the latter areas is temporarily aggraded above wave base, there wave and current action permit only sand deposition. Sands can be dispersed in this way onto the outer offshore zone of wide shallow shelves, as observed in the Mesozoic of the Rocky Mountain interior (Brenner and Davies, 1974, Berg, 1975; Spearing, 1975).

The history of continental glaciation during the Late Cenozoic serves as a model for understanding the relative effect of glaciation on eustatic sea-level changes and marine shelf sedimentation in late Ordovician and early Silurian times. During the formaticn of glaciers, water was gradually transferred from the seas to the ice, thus lowering sea level at a slow rate. Previous studies indicate that the Pleistocene epoch was preceded by a long-term cooling trend which extended over a period of several million years, and during which polar and subpolar ice caps grew and stabilized. Specific stages of glaciation were preceded by intervals of 20,000 to 50,000 years during which the continental ice sheets formed. In contrast, during periods of deglaciation water was returned to the seas in a third the time (Andrews, 1975). Major ice sheets melted within 10,000 years (Flint, 1971). The melting of the last Wisconsin ice sheets produced rapid initial rates of sea level rise - 20 to $30 \mathrm{~m}$ in the first 2,000 years (Bloom, 1971; Norner, 1975).
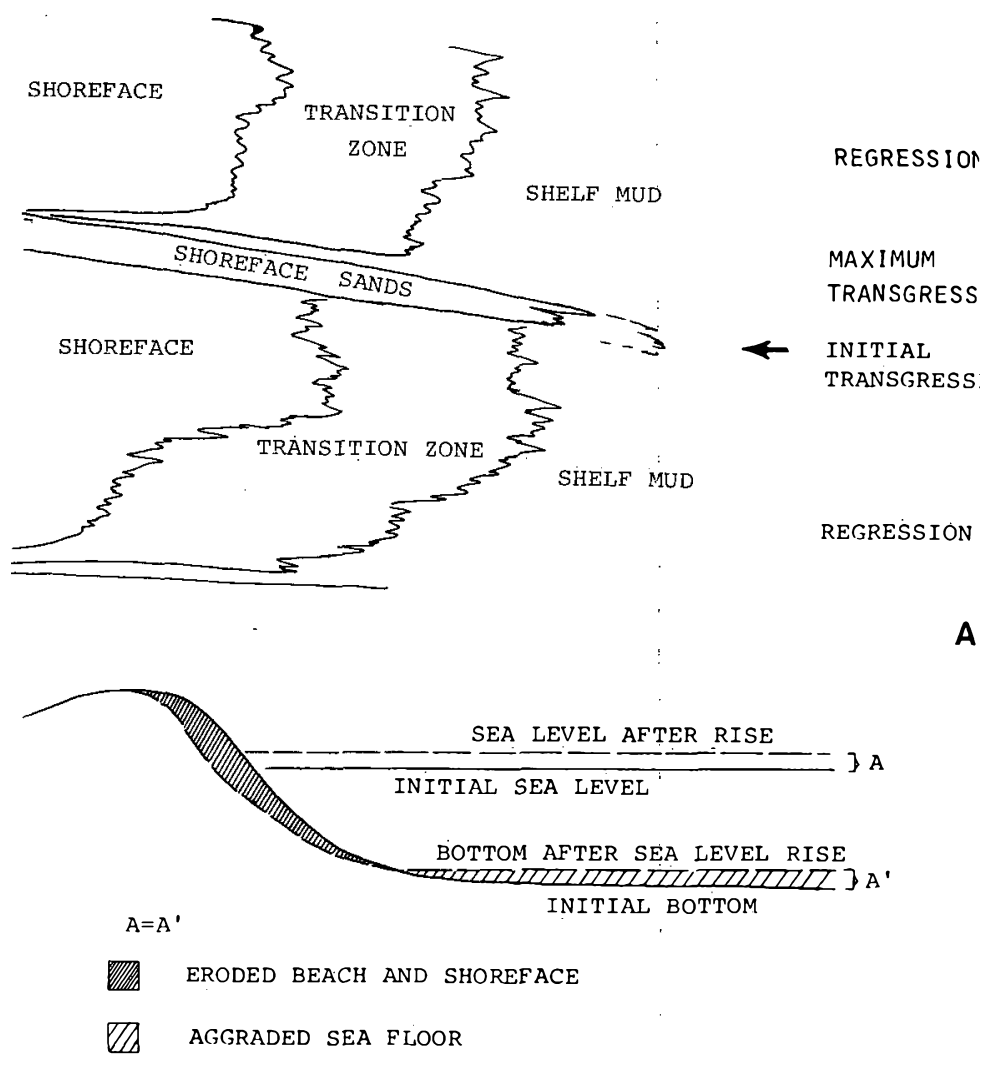

Fig. 6 (a) Model of shoreface to shelf facies associations in relation to regressive and transgressive phases of deposition.

(b) Bruun's coastal retreat model (modified after Schwartz, 1965). 
KENTVILLE FM

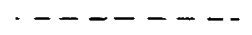

UPPER MEMBER

LOWER MEMBER

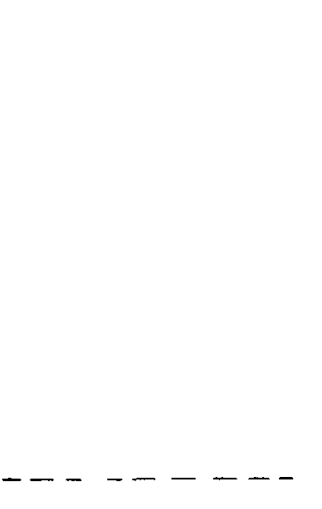

HALIFAX FM
WHITE ROCK FORMATION ALONG FALES RIVER

ROCKVILLE NOTCH, N.S.

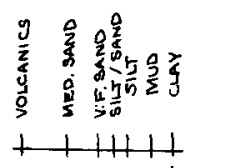$$
\text { com }
$$

INTERNAL COMPOSIMONAL /BEDDING TYPES
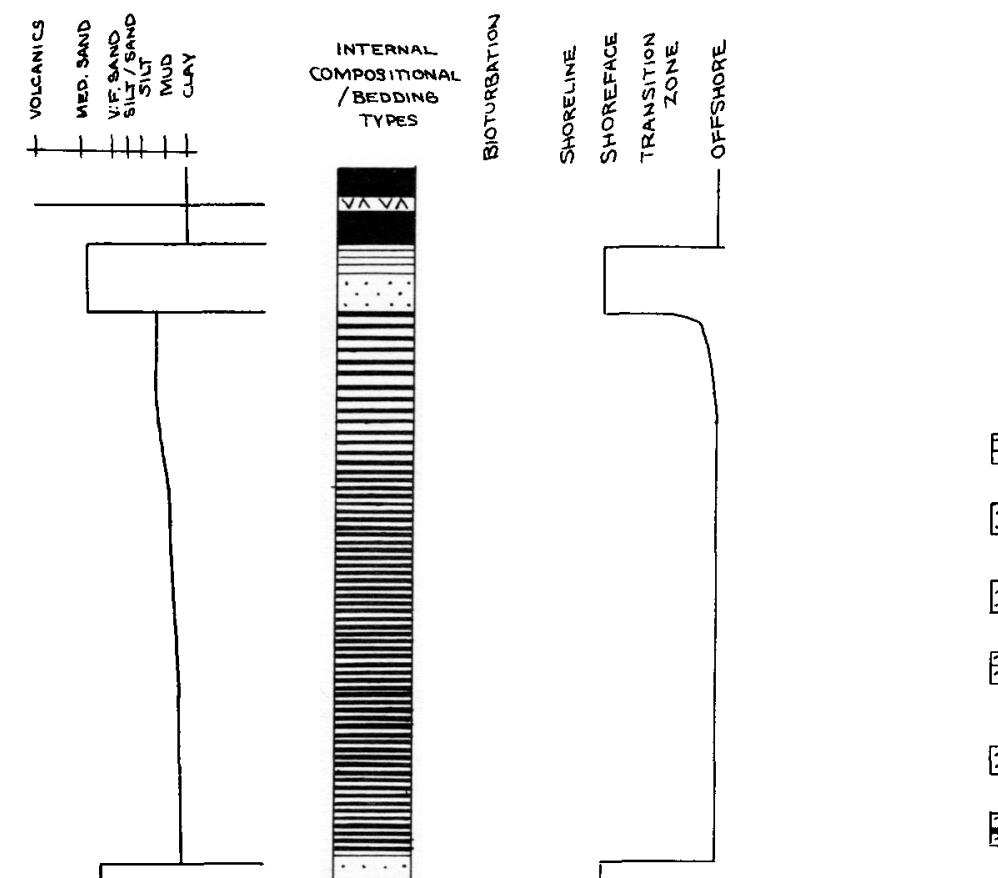

BEDDING TYPES

Parallel laminated QUARTZITE

MASSIVE QUARTZITE (STRUCTURELESS)

$\rightarrow$ LENTICULAR BEDDING (SILT/SAND)

च LENTICULAR BEDDING WITH CONTINUOUS QUARTZITE BEDS

च LENTICULAR BEDDING (SILT/MUD)

- Lenticular bedding (SILT/MUD) WITH ALTERNATING CLAY BEDS

च LENTICULAR BEDDING (SILT)

WITH VOLCANICAASTICS

- alternating

SILTSTONE/ SHALE BEDS

D. BlACK SHALE

V. VOLCANICS

PE POORLY EXPOSED

BASAG VOLCANICS
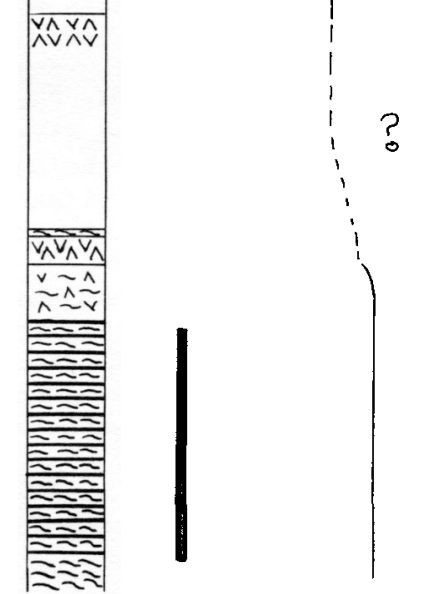

RHYOLITE VOLCANICS

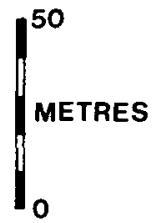

Fig. 7 Columnar section of the White Rock Formation at Fales River. 


\section{THE FALES RIVER SECTION}

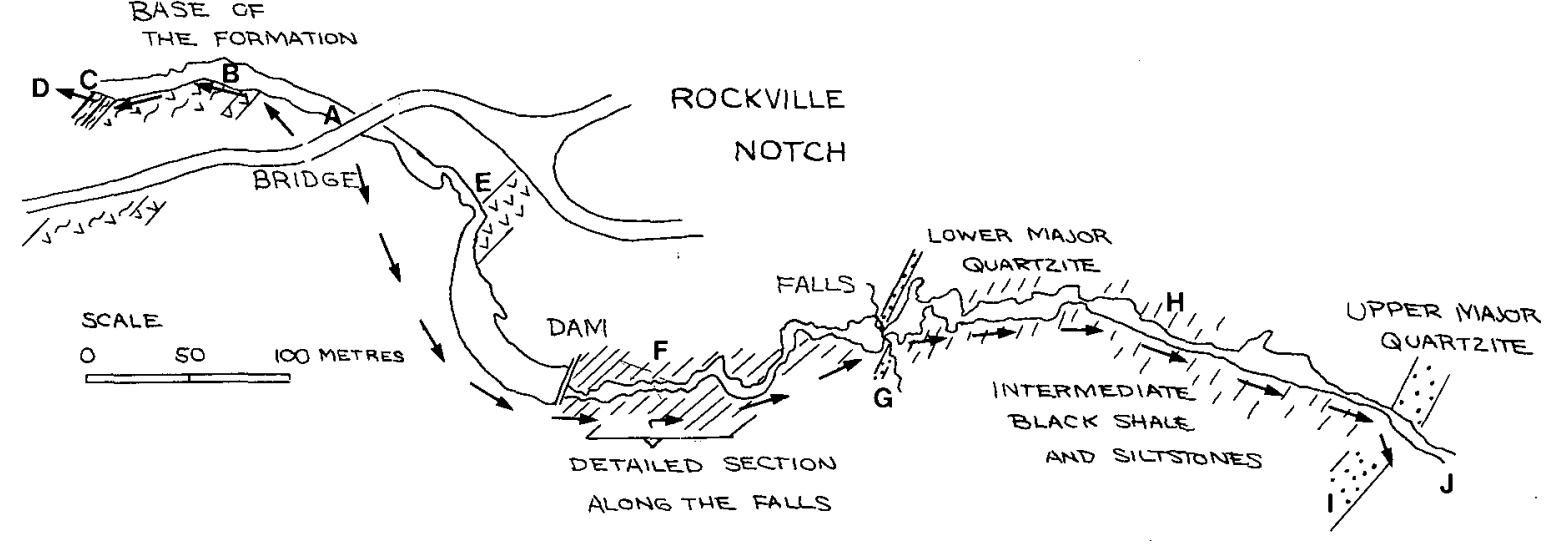

Fig. 8 The Fales River section of the White Rock Formation (Stop 4). Arrows indicate route of foot traverse.

The stratigraphy of the White Rock Formation records the effect of these types of glacio-eustatic changes on shallow marine sedimentation (summarized in Fig. 5). The regression represented by the uppermost strata of the Halifax Formation reflects a decrease in sediment supply, largely in response to the consumption of sediment by the construction of nearshore complexes along a readjusted shoreline. The overlying, markedly diachronous arenites of the White Rock lower member reflect gradual progradation of a sandy nearshore zone over a shallow sea floor. In contrast, transgression initiated rapid sedimentation in the basin peripheral to the coast. The widespread deposition of the sheet-arenites began and ended abruptly, as the sea transgressed. The deposition of these strata may have been related to worldwide transgressions during the Late ordovician, probably associated with major deglaciation episodes (Bridges, 1975).

\section{Field-rip stop at Fales River}

One of the more continuous exposures of the Middle Paleozoic rocks (upper Halifax, White Rock and Kentville Formations) in the Meguma Belt occurs along Fales River. Most of the facies relationships discussed above are visible at this section. Directions to the locality (Stop 4) are indicated in Figure 2. Figure 7 is a stratigraphic column of the Fales River section, and Figure 8 is a sketch map showing the location of these rocks. Figures 9 through 22 show examples of the sedimentary structures and rock types to be seen at this section (although some of the photographs are from other localities).

The section is located near the bridge at Rockville Notch (Fig. 8). The strata are vertically dipping on the north limb of a northeast-southwest trending syncline (Figs. 1A, 2). The major part of the section crops out on the northeast side of the stream. The lower felsic volcanics of the White Rock Formation and the slates of the Halifax Formation crop out on the south side of the bridge. The White Rock Formation also crops out for a distance of $700 \mathrm{~m}$ downstream (North) from the bridge (Fig. 8). The stations referred to below are located by the letters $A$ to $J$ in Figure 8 .

Stations $A$ and $B$. The part of the section that lies south of the bridge is approached along the. east bank of the river by walking through the woods to stream level and then proceeding upstream. Immediately below the bridge is a diorite sill. An outcrop of felsic ash (a devitrified prophyritic tuff) altered to a buff-weathering carbonate rock crops out a distance of $40 \mathrm{~m}$ upstream. The stratigraphic thickness of the beds exposed at this outcrop is $30 \mathrm{~m}$. This rock marks the base of the White Rock Formation.

Station C. Gray slates of the underlying Halifax Formation crop out a little further upstream. The first outcrops exhibit a distinctive pelitic lithology, restricted to the uppermost 100 of the Halifax Formation. Note the alternation of the light grey, silt laminae and microlenses with continuous laminae of dark grey slate. Numerous impressions of small horizontal animal traces are preserved on bedding surfaces. The percentage of carbonaceous, micaceous laminae and of burrows is higher here than in the slates $80 \mathrm{~m}$ further upstream.

Station D. The Halifax slates farther upstrearl (but downsection) have an increased number 
WHITE QUARTZITE

GRAY QUARTZITE

(SANDY SILTSTONE)

- SILTY MUDSTONE

$\propto$ FINE LENSES

2 PARALLEL

LAMINATION

THOROUGH

BIOTURBATION

PARTIAL

BIOTURBATION

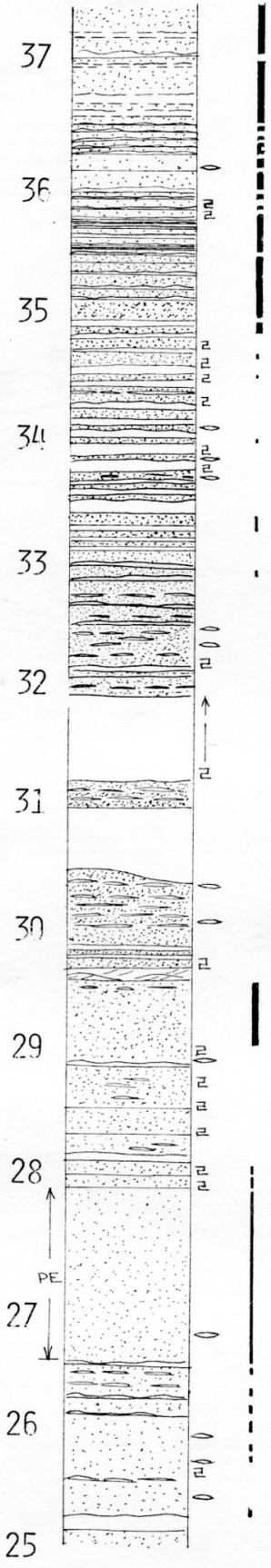

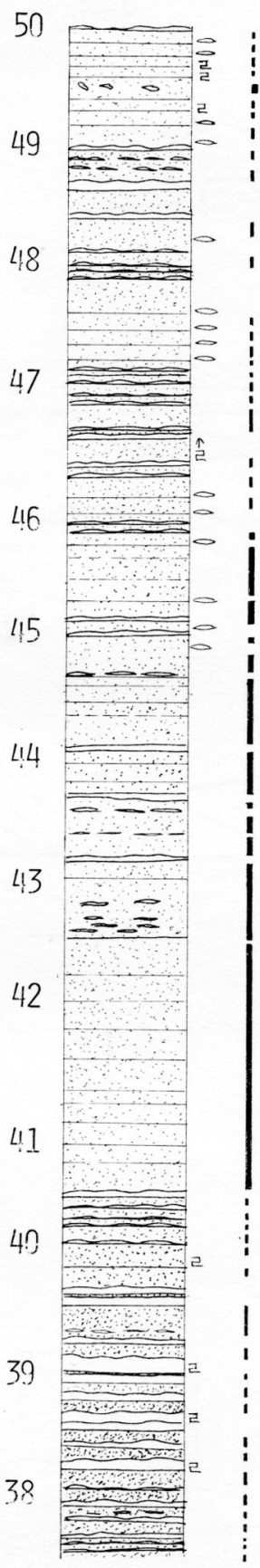

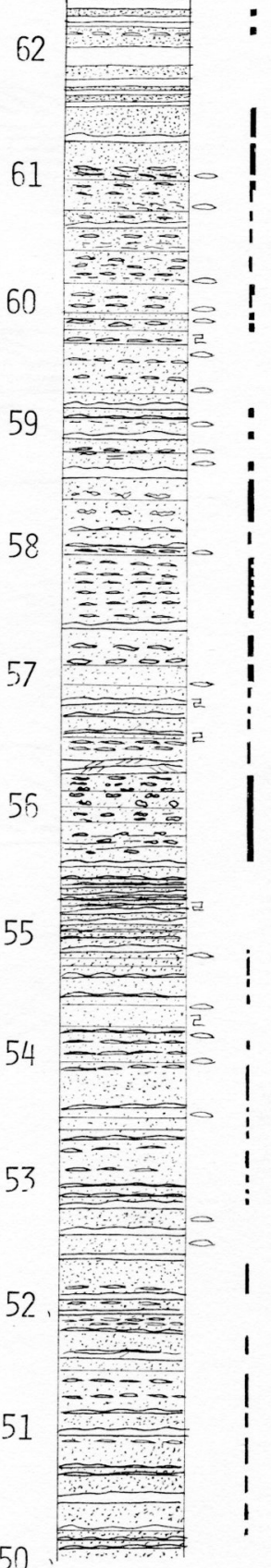

Fig. 9 Detailed log of part of White Rock Formation upstream and to east of Fales River Falls. Numbers to left of columns, starting $25 \mathrm{~m}$ stratigraphically above dam (see Fig. 8 ) give vertical scale in metres. Distinguishing bedding characteristics and internal sedimentary structures throughout section are as follows: $25-28 \mathrm{~m}$, bioturbated siltstones with minor arenites; 28-32m, lenticular, very thin beds of fine-grained arenite interbedded with siltstone, above and below two thick-bedded arenites. Minor bioturbation and a high percentage of siltstone in strata bounding the thick arenites; $33-35 \mathrm{~m}$, arenite beds $(10 \mathrm{~cm}$ thick, laminated bases, rippled tops) interbeddedwith laminated siltstones; $35-37.5 \mathrm{~m}$, very thin bioturbated arenite beds (average thickness $-1 \mathrm{~cm}$ ); $37.5-40.5 \mathrm{~m}$, arenite beds $(5$ to $10 \mathrm{~cm}$ thick) interbedded with bioturbated siltstone; $40.5-45 \mathrm{~m}$, highly bioturbated siltstone; $46-50 \mathrm{~m}$, minor biofurbation, basal parts extensively laminated; $50-56 \mathrm{~m}$, numerous arenite beds ( 2 to $7 \mathrm{~cm}$ thick), bioturbation siltstones and upper parts of arenites; $56-61 \mathrm{~m}$, lenticular, very thin beds of arenite common, minor bioturbation; $61-62.5 \mathrm{~m}$, lenticular, thin to medium beds $(8$ to $35 \mathrm{~cm}$ thick) of arenite bounded by siltstone interbedded with very thin $(5 \mathrm{~cm})$, laterally continuous beds of arenite. 

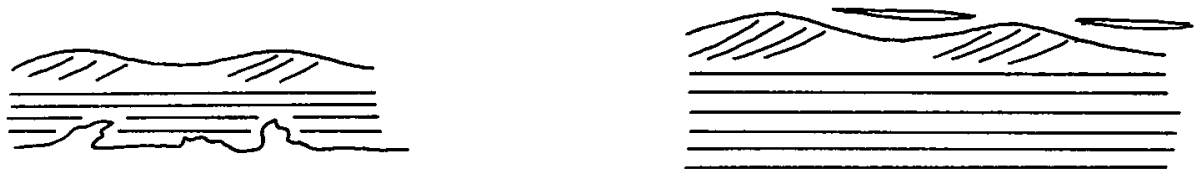

A

B
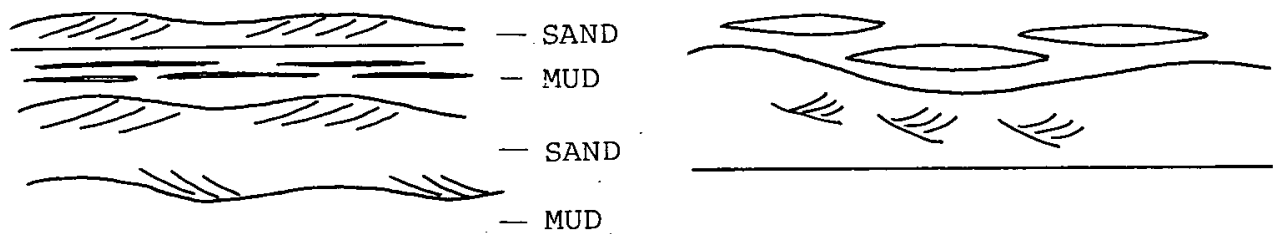

- MUD

C

D
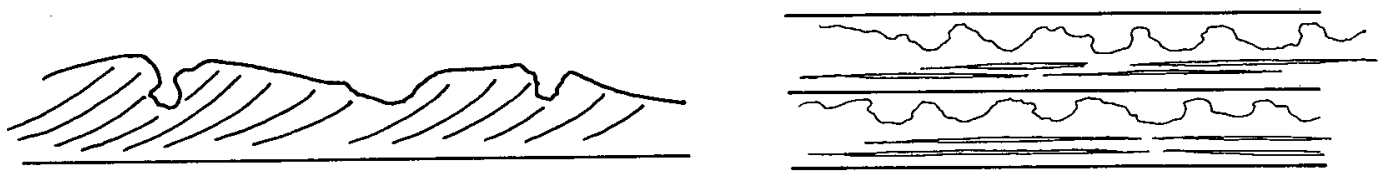

$\mathbf{E}$

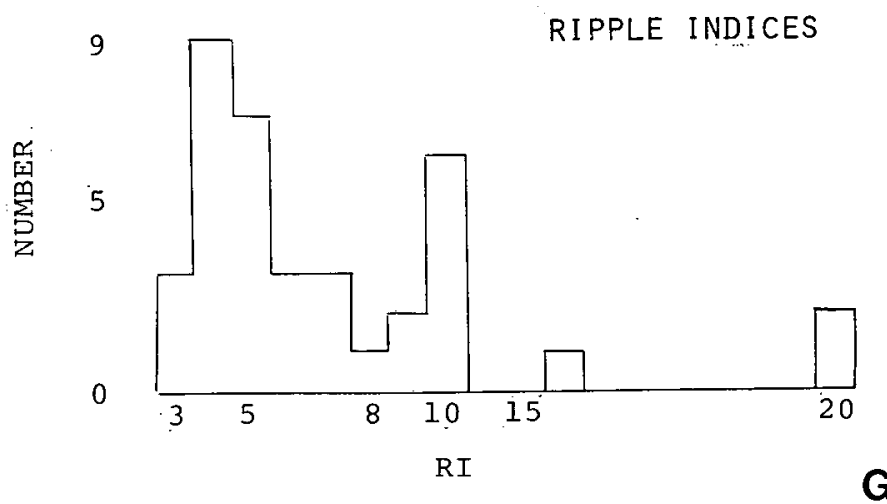

Fig. 10 Sketches of beds observed in outcrops at Fales River Falls (scale $1 \mathrm{~cm} \equiv 5 \mathrm{~cm}$ ).

(a) Arenite bed with parallel-lamination and ripple cross-lamination. Irregularities at the base are possible escape burrows.

(b) Arenite bed with parallel-lamination and ripple cross-lamination, succeeded by siltstone containing discontinuous lenses of arenite.

(c) Ripple cross-laminated arenite interbedded with mudstone containing siltstone lenses.

(d) Arenite bed with ripple-lamination throughout, succeeded by siltstone with lenses of arenite.

(e) Arenite bed with ripple cross-lamination and irregular top. The latter is a product of the burrowing activity of organisms.

(f) Sandy siltstone beds with irregular tops due to burrowing. The lenses are composed of very fine-grained orenite.

(g) Histogram of ripple indices (wave length/ripple height) at Station F (see Fig. 8 for location). 


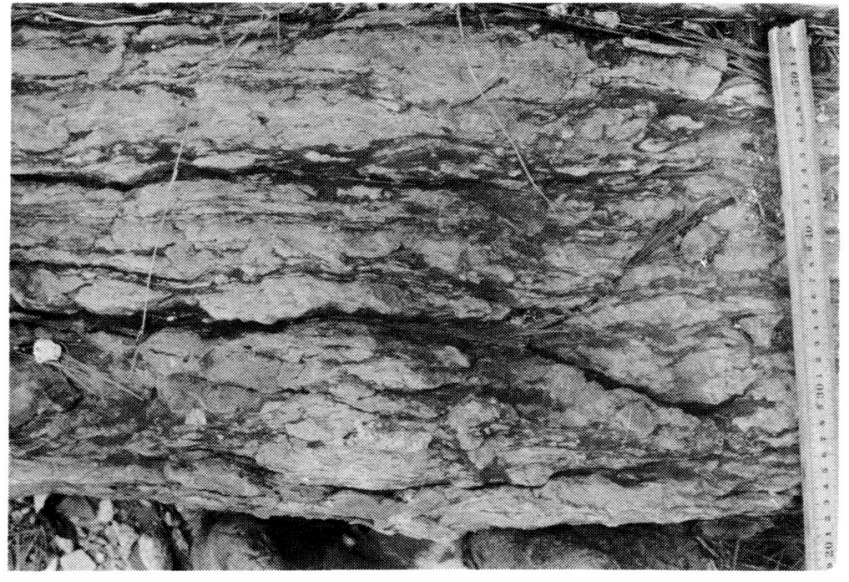

Fig. 11 Irregular and mottled (bioturbated) beds of arenite and siltstone, Fales River Falls. Scale is in centimetres.

of silt-rich microlenses, while the intercalated micaceous (mud) layers are, relative to the slates above, reduced to microlaminae. Interpersed ripple trains of light-colored cross-lominated lenses of quartzose siltstone and very fine-grained arenite are diagnostic of this facies (see Fig. 17). The presence of abundant silt- and sand-sized sediments, moderate bioturbation, and macroscopic current structures reflects the more current-dominated origin of these slates as compared with those exposed at the top of the formation. Outcrops still farther upstream indicate that this litholooy persists downsection in the Halifax Formation over an interval of at least $1800 \mathrm{~m}$.

Station E. Returning downstream to the White Rock Formation, immediately north of the bridge, there is a 100-m unexposed gap in the section along the river's east side up to the dam, but pillow basalts crop out on the west bank (Fig. 8). The pillow structures are zoned, with coarsely crystalline outer portions, and "chilled" microcrystalline rims. Euff-weathered limestone typically occurs between the pillows.

Station F. Sedimentary rocks of the overlying portion of the White Rock Formation crop out to the north of the dam (Fig. \&). The dam is approached along a trail which begins east of the bridge and contours the hillside $20 \mathrm{~m}$ above the river. Immediately below the dam the rocks crop out along the river bed. Stream-jank exposures of quartz arenite occur a little further upstream. Ps rough path continues high above the river along the east crest of the gorge and provides a quick return route to the bridge.

Very even and laterally continuous beds of flaggy, grey-weathering quartzite (Fig. 18) crop out over a stratigraphic interval of $80 \mathrm{~m}$ between the dam and the base of the falls (stratigraphically beneath the "lower major quartzite", Fig. 8). The internal sedimentary structures of these strata can be observed on the rock terrace above the falls. The stratigraphy of this part of the section is summarized in Fig. 9. The excellent exposures here provide insights as to the formative sedimentary processes, hence, the rocks are discussed in some detail below.

The lithologies and sedimentary structures of these strata are characteristic of Facies 3. The predominant beds are laminated and bioturbated, grev, sandy siltstones alternating with very thin-bedded white arenites and thin laminae of red mudstone (Figs. 11 through 14). The siltstones consist of alternating thin laminae of light grey, well sorted, coarse, quartzose siltstone and dark grey, moderately sorted, fine, micaceous (muddy) siltstone (Figs. 12, 13). Horizontal burrows are commonly present between laminae. These siltstones generally have a mottled appearance as a result of biogenic reworking (Fig. J.1).

The arenites are composed of well sorted, very fine-grained quartz sand and most commonly appear as discontinuous lenses (herein termed lenticular bedding) within the siltstones at the $50-$ to $56-\mathrm{m}$ interval (Figs. 12, 23). Internally, the lenses are cross-laminated (Figs. 10C, 10E). Some arenites occur as thin continuous beds $(5$ to $10 \mathrm{~cm}$ thick) which have flat, sharp lower contacts, parallel-lamination near the bases, cross-jamination near the tops, and wavy upper contacts (Figs. 10A, 10 $E, 14)$. I few thick lenticular beds (6 to $10 \mathrm{~m}$ wide by 30 to $50 \mathrm{~cm}$ thick) of arenite are present. These beds generally have parallel-lamination and relatively flat bed contacts (Fig. 9, 30m to $32 \mathrm{~m} ; \mathrm{Fig} .18$, left side), hut occasionally possess medium- to largescale cruss-jamination. In contrast to the siltstones, the arenites commonly are relatively little affected by bioturbation.

Systematic variation of these lithologies through the section and the extent of bioturbation associated with them reveal a rhythmic sedimentary pattern (Fig. 9). Mudstone laminae are interstratified with the siltstone-arenite layers at regular intervals (every 5 to $10 \mathrm{~cm}$ ) (Figs. 13, 14, 16). Within the 5- to $10-\mathrm{cm}$ thick layers of arenite and siltstone, primary sedimentary structures are commonly preserved in the lower parts of the layers, rut are consistently obliterated by bioturbation near the tops of the layers (immediately beneath overlying mudstone laminae) (Figs. 10F, 12, 13). In the siltstones; burrows are numerous and tend to increase in abundance with decreasing grain size. The arenites are much less bioturbated, and tend to be disturbed only by burrows that descend from above (Fig. 1OE), or by escape tubes that penetrate from below (Fig. 10A). 


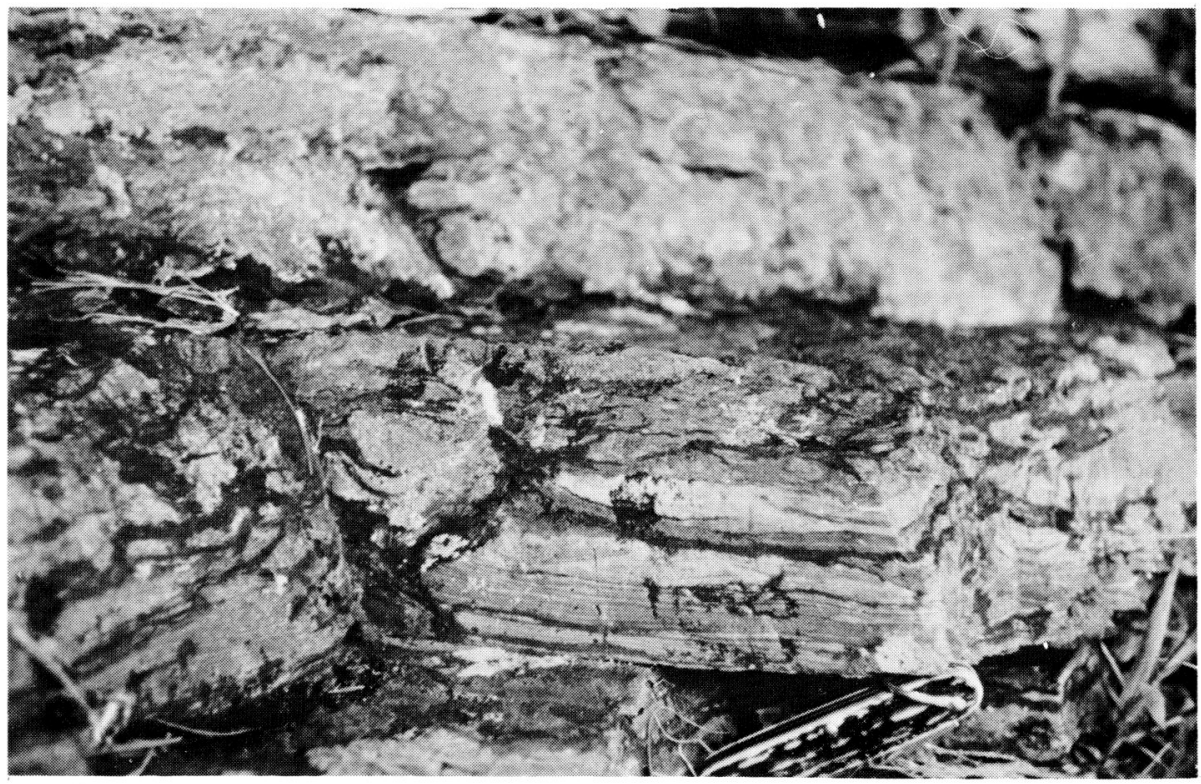

Fig. 12 Laminated siltstone beds and arenite lenses, Fales River Falls. Tops of beds dis. rupted by burrows of organo isms. Pocket knife is $5 \mathrm{~cm}$ long.

Fig. 13 Laminated beds of siltstone with thin interbeds of mude stone, Fales River Falls. Note wellopreserved laminae at the base and bioturbation at the top of bed in right centre of photograph. Scale is in inches.
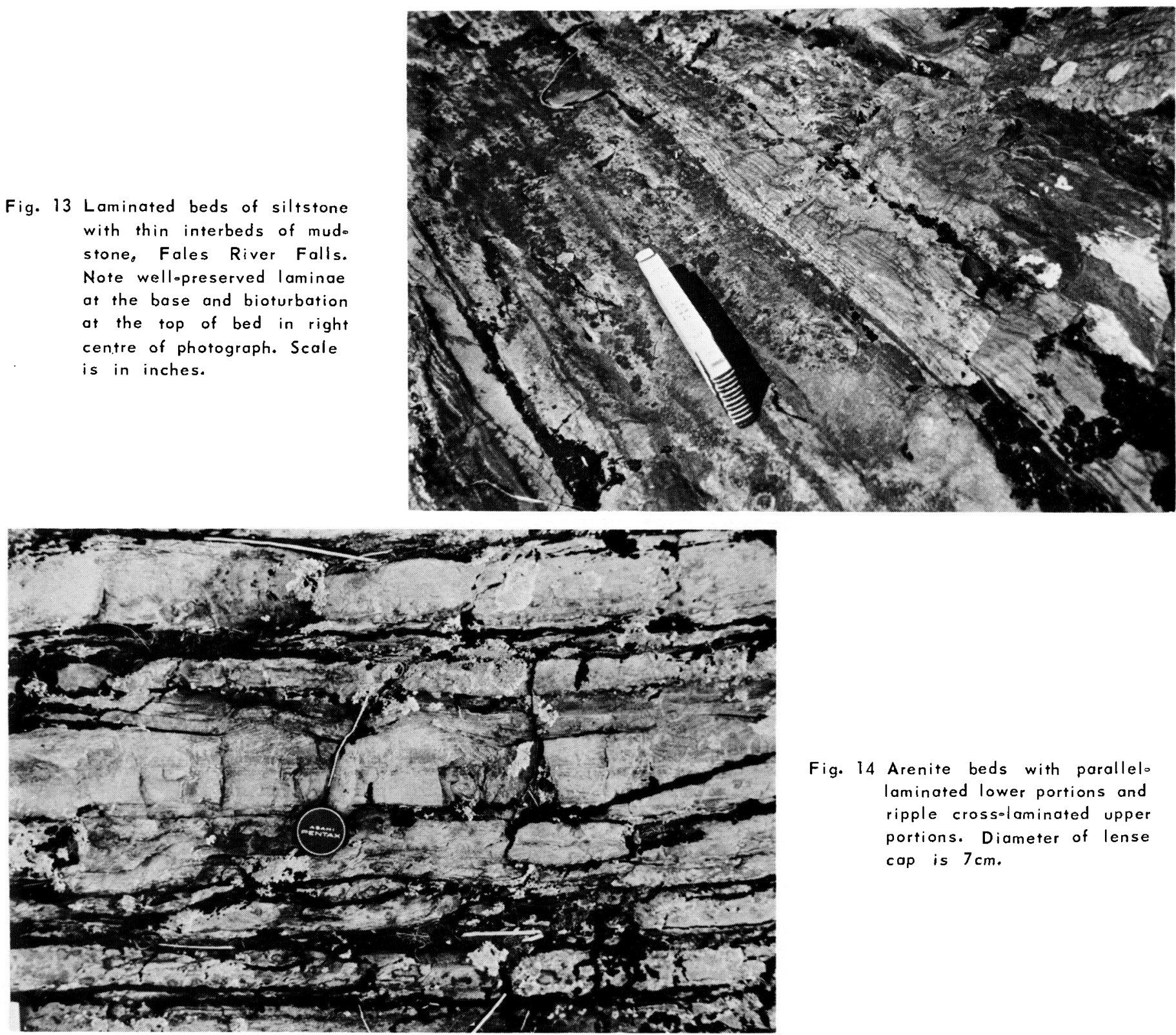

Fig. 14 Arenite beds with parallelo laminated lower portions and ripple crosselaminated upper portions. Diameter of lense cap is $7 \mathrm{~cm}$. 


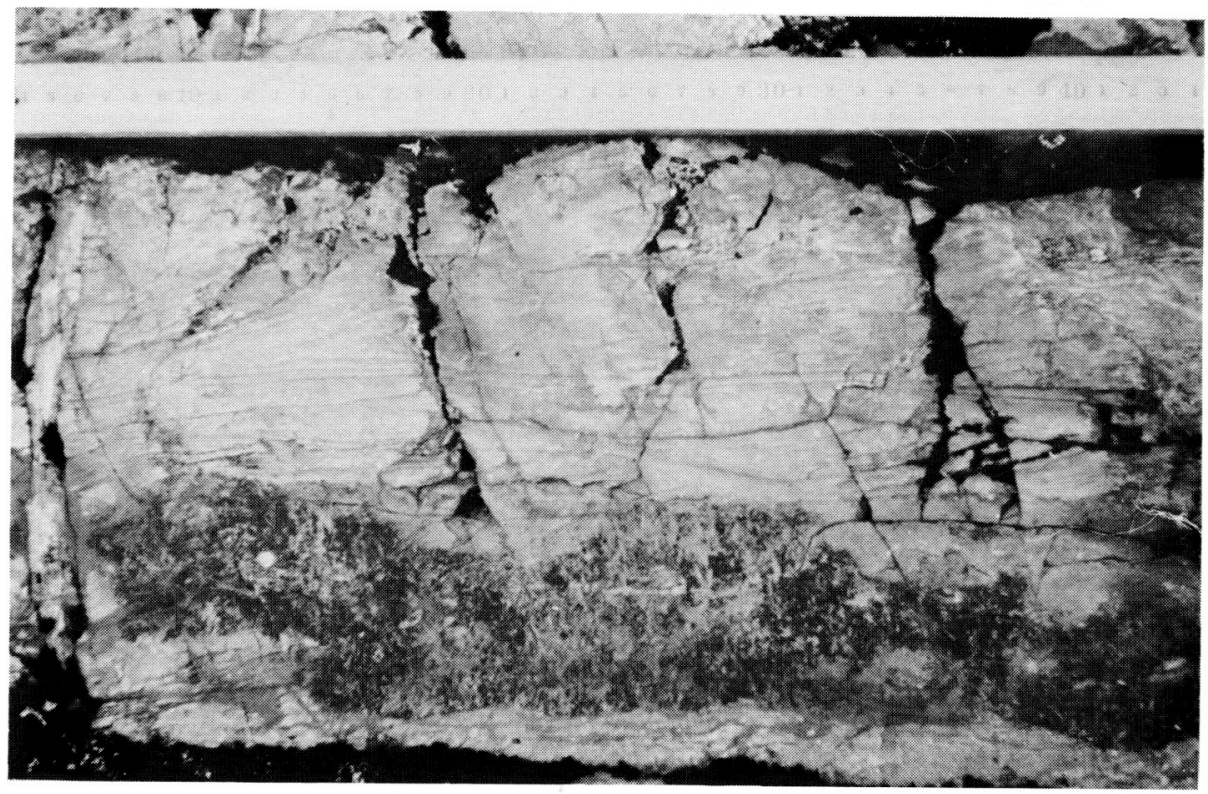

Fig. 15 Arenite bed containing a como posite of crosso and parallelo laminated layers, Fales River Falls. Bundleowise upbuildo ing of crossolaminae is charo acteristic of "waveripple" bedding. Scale is in centio meters.

Fig. 16 Rhythmically laminated aren ite with interbeds of red mudo stone, South Harmony, 3 miles $(5 \mathrm{~km})$ east of Fales River Falls. From the end to the first joint of the rule is $11 \mathrm{~cm}$.

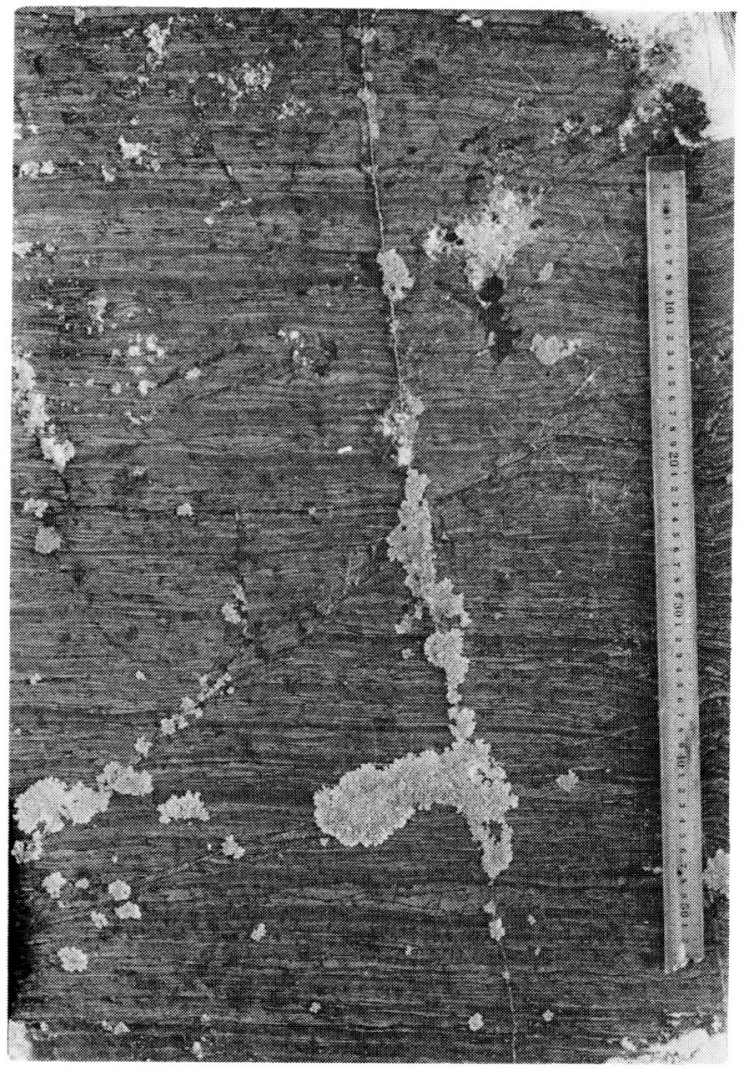

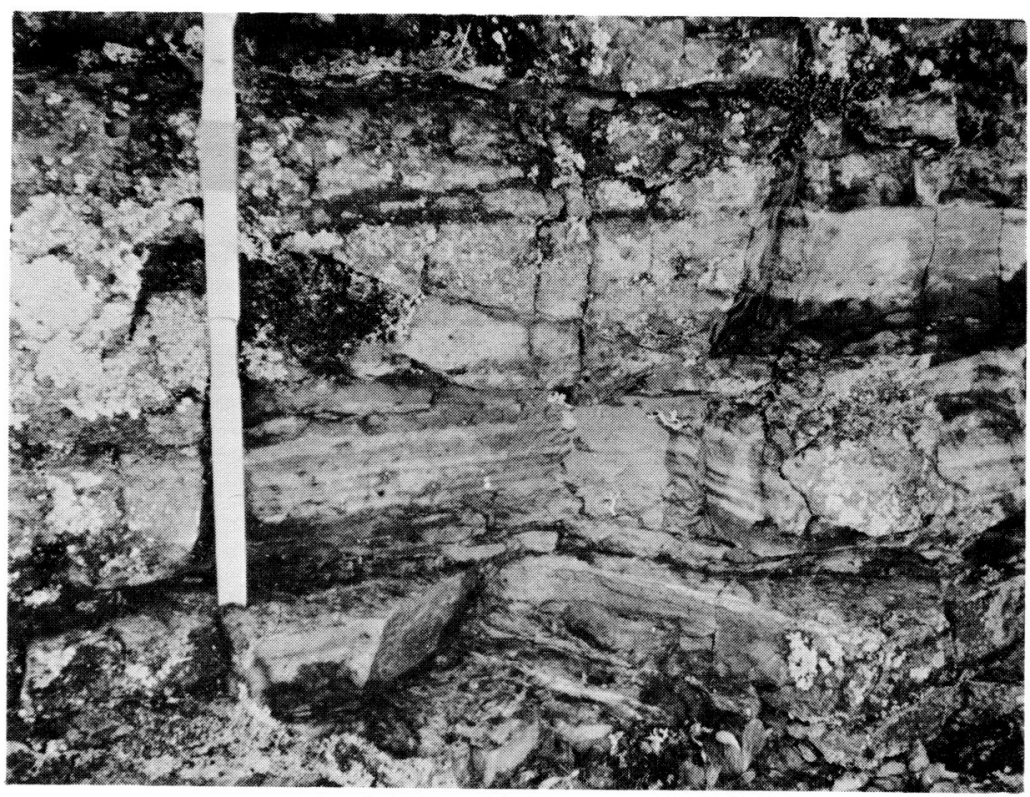

Fig. 17 Shale with thin siltstone lenses, upper Halifax Forma tion, Nictaux Falls, 6 miles $(10 \mathrm{~km})$ west of Foles River Falls. Scale is in centimetres. 


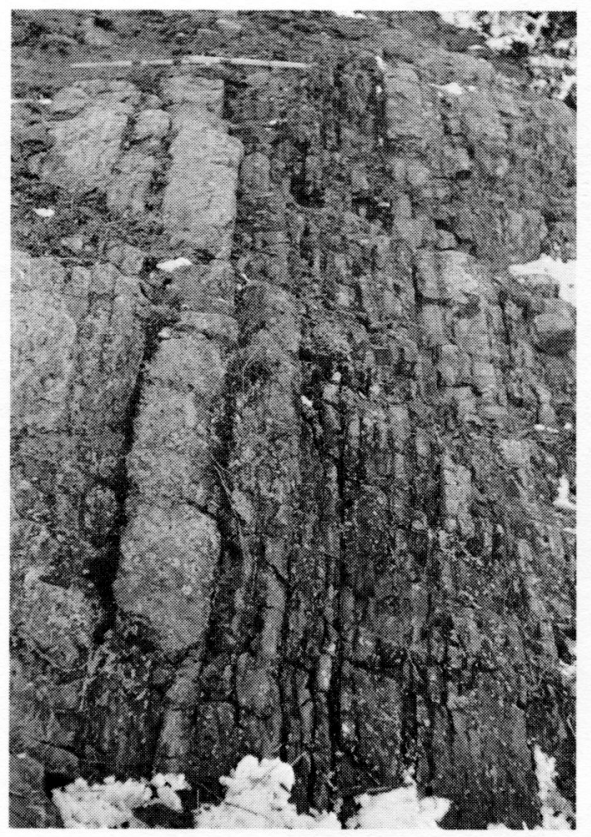

Fig. 18 Beds of quartz arenite, 30 to $50 \mathrm{~cm}$ thick (at left) and thin interbeds of arenite, siltstone and mudstone (at right), tops facing left, South Harmony, 3 miles (5 $\mathrm{km}$ ) east of Fales River Falls. Rule at far end of the outcrop if $1 \mathrm{~m}$ long.

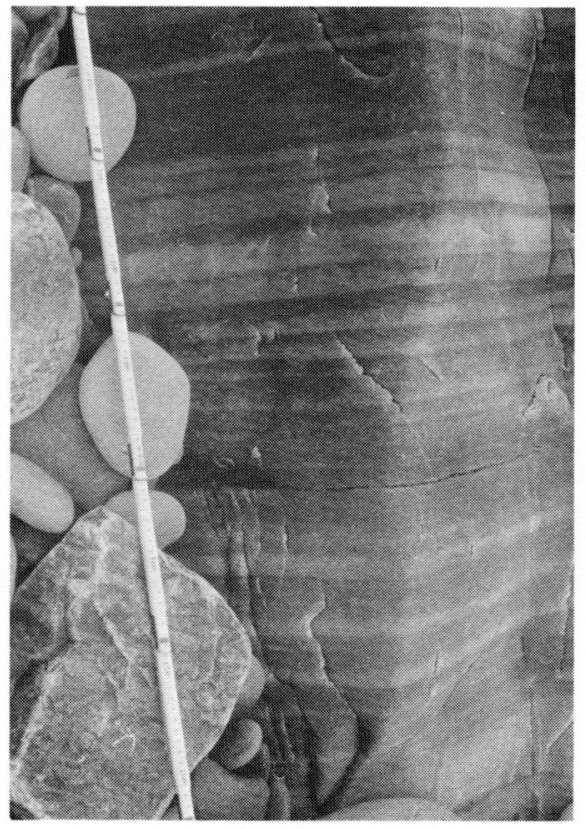

Fig. 20 Rhythmically bedded, thin quartz arenites and dark siltstones, tops facing up. Siltstones are biofurbated. Yarmouth area, southwestern Nova Scotia. Scale is in centimetres.

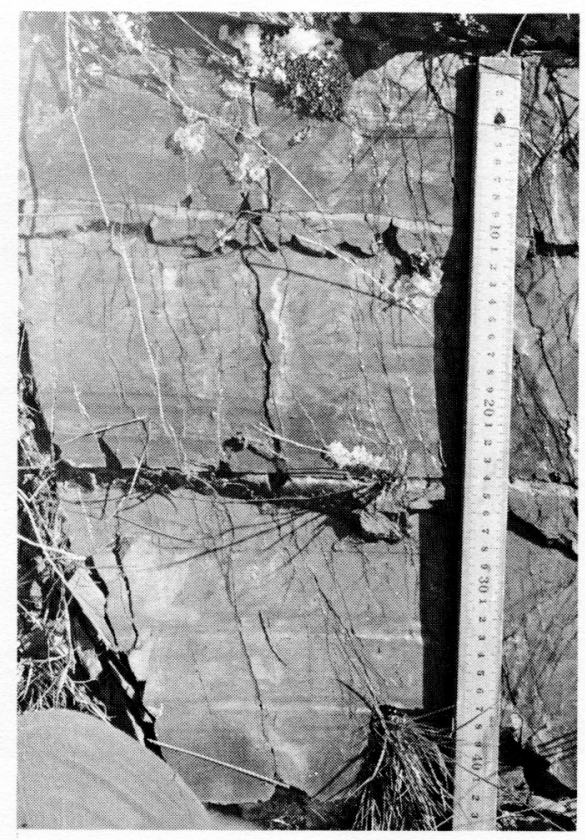

Fig. 19 Three successive beds of parallel-laminated quartz wacke, each consisting of poorly sorted wackes at the base grading to more arenitic rock at the top. Tops capped by clay drape laminae. Nictaux Falls, 6 miles $(10 \mathrm{~km})$ west of Fales River. Scale is in centimetres.

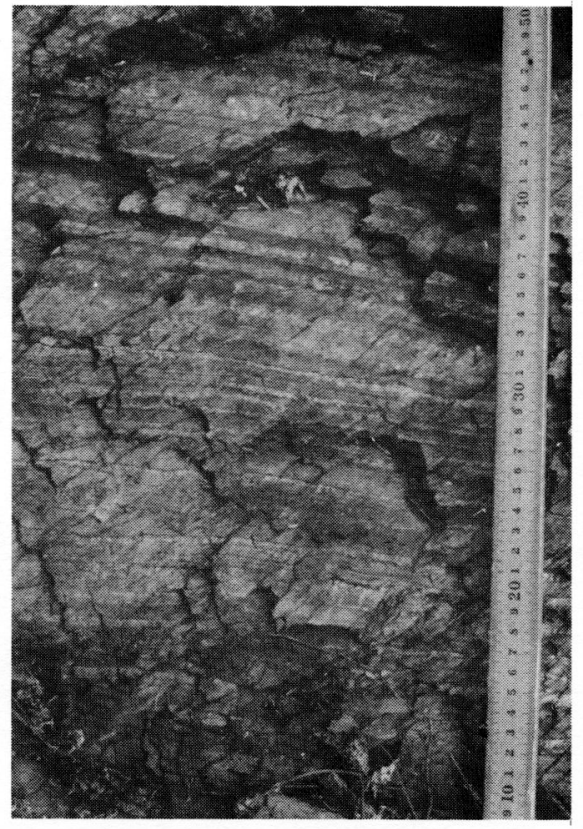

Fig. 21 Alternating laminae of siltstone (light-coloured) and shale (dark-coloured), tops facing up. Load casts are common at base of siltstone beds. Upper part of White Rock Formation, Fales River section. Scale is in centimetres. 


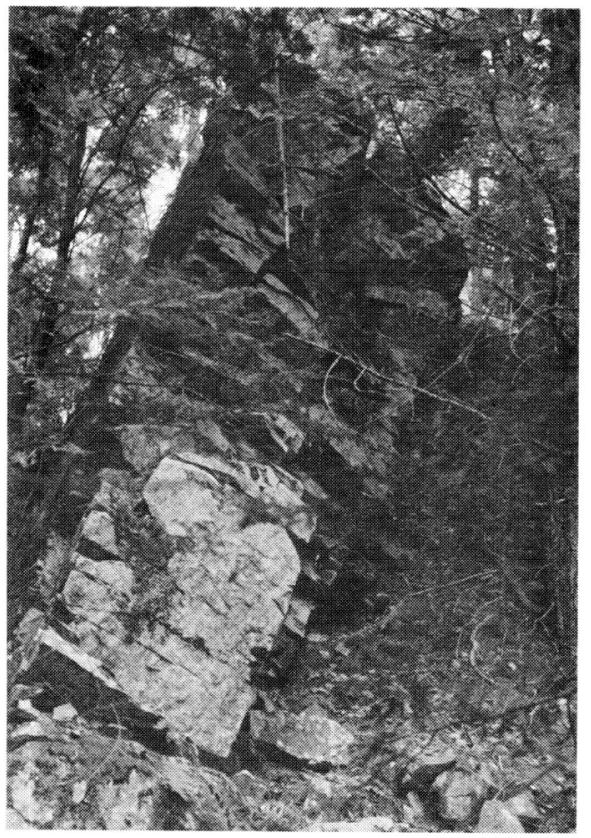

Fig. 22 Massive quartz arenite bed (1.5m thick), top of White Rock Formation, Fales River Section.

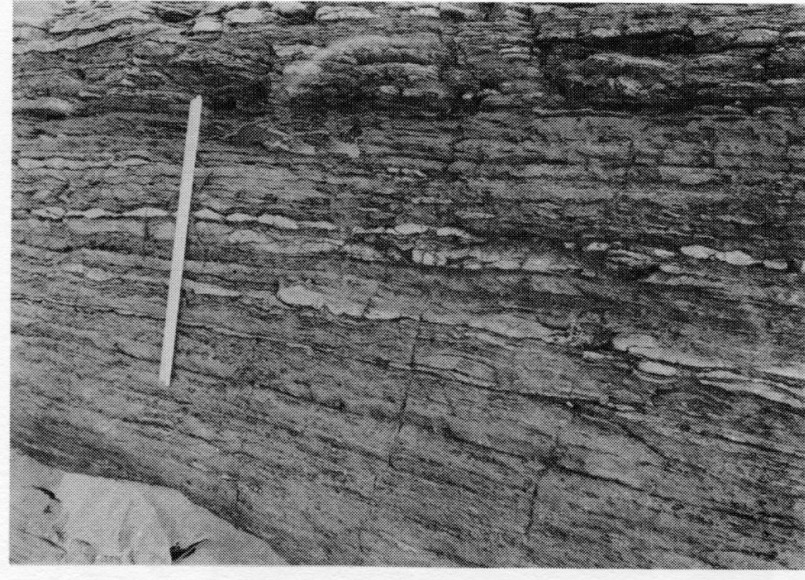

Fig. 23 Lenticular bedding, consisting of very thin, lenticular arenite beds in silty shale, top of the White Rock Formation, Cape St. Mary, southwestern Nova Scotia. Length of scale is $50 \mathrm{~cm}$.

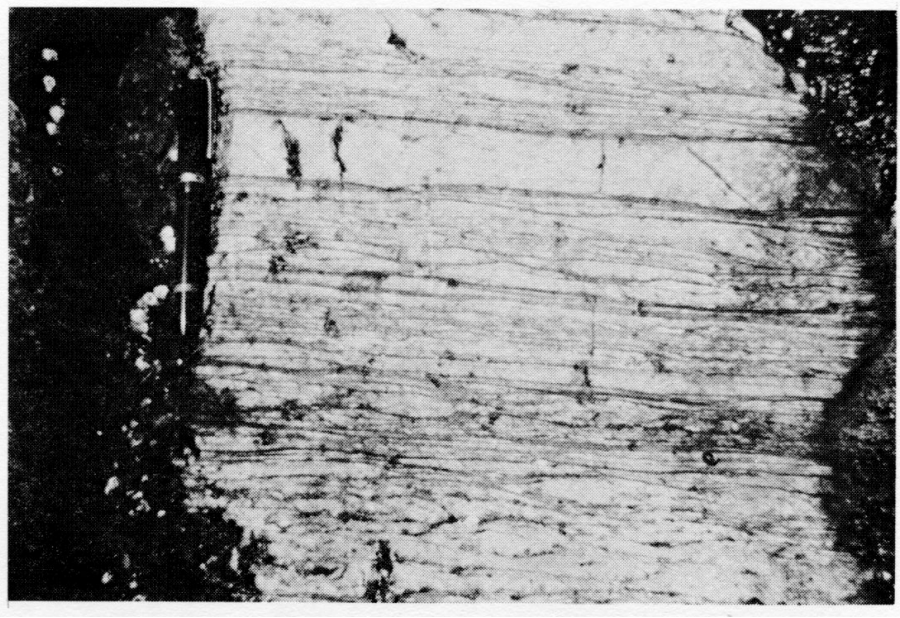

Fig. 24 Lenticular and flaser lamination and wavy bedding. Thin arenite beds are infercalated with quartzose siltstone microlenses and micaceous partings. Yarmouth, southwestern Nova Scotia. Pen is $7 \mathrm{~cm}$ long. 


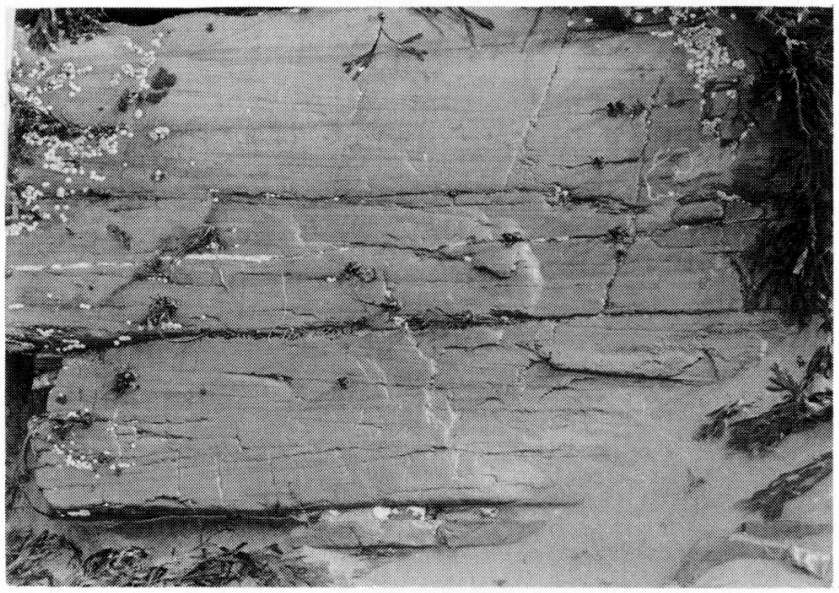

Fig. 25 Quartz arenites with characteristic, small-scale planar cross-laminated sets interbedded with thin, paral. lel-laminated layers. Note gently inclined tangential cross-laminae filling wide troughs (average 4 metres wide by $10 \mathrm{~cm}$ deep). Beds shown here are approximately $40 \mathrm{~cm}$ in total thickness. Cape St. Mary, southwestern Nova Scotia.

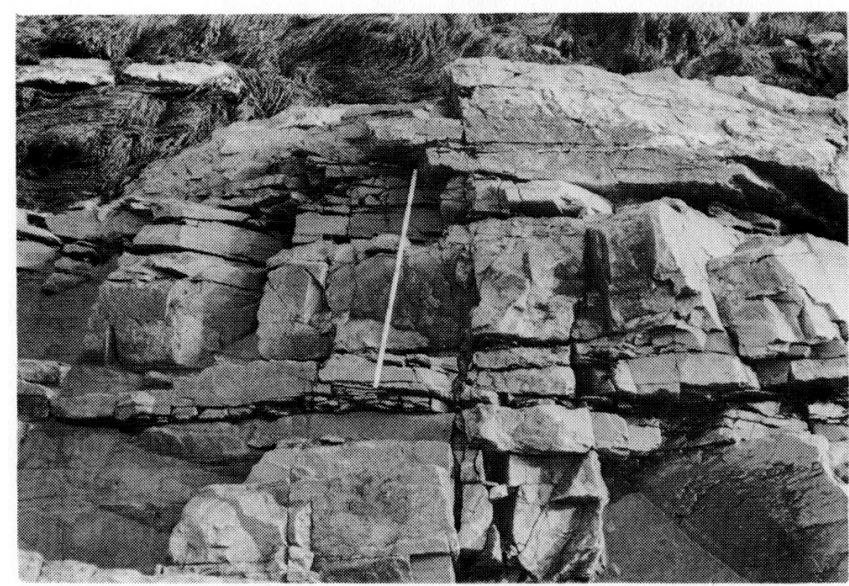

Fig. 27 Quartz arenite beds interlayered with minor siltstone. The relatively thick beds $(50-80 \mathrm{~cm})$ are massive and the thinner beds are cross-laminated. Length of measuring stick is $2 \mathrm{~m}$.

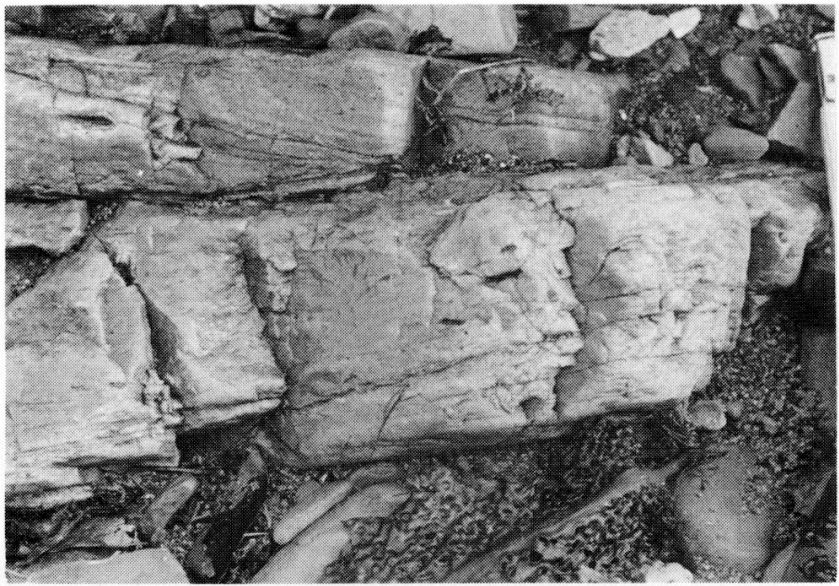

Fig. 26 Large-scale, cross-laminated sets in quartz arenites. Note opposing directions of inclination (possibly resulting from ebb- and flood-tide currents). Aggregate thickness of beds is approximately $30 \mathrm{~cm}$. Cape St. Mary, southwestern Nova Scotia.

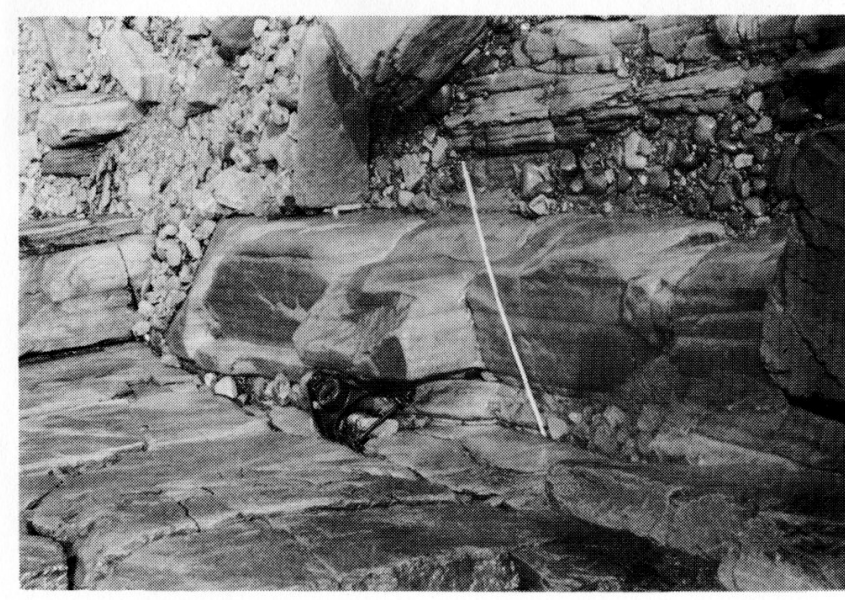

Fig. 28 Thick $(90 \mathrm{~cm})$ quartz orenite bed with parallel lamination, Cape St. Mary, southwestern Nova Scotia. Length of the measuring stick is $2 \mathrm{~m}$. 
The rhythmic pattern of sedimentation suggests that the sediments were deposited episodically. Muddy silt and sand accumulated rapidly in beds 5 to $10 \mathrm{~cm}$ thick. Silt was deposited at a decreasing rate upwards within these layers, and organisms were able to graze at the surface of each successive lamina. A significant time period intervened between the deposition of each silt-sand layer. At these times minor amounts of mud accumulated slowly while burrowing organisms penetrated the top of the underlying layer. Such periods of very slow deposition were shorter during times of increased sand supply (evident from decreased bioturbation). The nearly consistent thickness of the repeated silt-sand layers is an unexplained curiosity, apparently related to regular fluctuations in processes and sediment supply.

The internal form of the arenites provides further clues as to the nature and origin of these strata. The lack of burrows between laminae is evidence of rapid deposition. Other criteria support this conclusion: 1) the sharp contacts of the beds, 2) basal load casts, and 3) the vertical transition from parallel-lamination to crosslamination in relatively thin beds, reflecting, in each case, the decreasing energy during continuous flow of a depositional current. Paleocurrent data obtained from the cross-laminae and ripple marks indicate a dominant, northwest to southwest trend (Fig. 3C, 3D). The association of the cross-laminae with, first, straight-form ripple crests with low ripple indices (wave length/ ripple height $=4$ to 8 ; ig. $10 G$ ), and, secondly, with some characteristic bundle-vise upward cross-sets (Fig. 15), suggests that they originated from asymmetric wave ripples. Thus these sandy deposits are apparently related to winnowing and transport by regional, wave-generated currents parallel to the paleoshore (Fig. 3D). The pulsating nature of the deposition may have resulted from regular, seasonal, storm-wave surges.

Station G. Moving on to the next outcrops upsection, below the falls and beyond a covered interval, the lower sheet-arenite beds of the upper member form massive palisades of rock on both sides of the river (Lower Major Quartzite, Fig. 8). Dedding planes are difficult to discern in these quartz arenites, due to the massive, texturally homogeneous nature of the rock, and the presence of numerous joints, fractures, and a local fault. Black slates and siltstones are in fault contact with the arenites. Thin-bedded siltstones beneath the quartzites are poorly exposed high on the east bank. Red siltstones and silty arenites cropping out on the stream bed are presumed to overlie the quartzites. Rlack laminite slates abruptly overlie the siltstones along the stream bed. Due to local faulting and fracturing along the boundary of these facies, the transitional relationships generally are not clear.

Station H. Further downstream, overlying black slates crop out along the east side of the river for a distance of $220 \mathrm{~m}$. The slates are partially duplicated by a minor open fold and several faults. The estimated stratigraphic thickness represented by these outcrops is between 80 and $120 \mathrm{~m}$. Even, laterally continous, and graded laminae of quartzose siltstone are interlayered in the slate. The siltstones increase in abundance upwards from thin laminae forming $10 \%$ of the rock at the base to laminae about $1 \mathrm{~cm}$ thick and generally forming $65 \%$ of the rock at the top (a lithology of alternately bedded siltstone and slate, Fig. 21). These laminite slates lack lenses with cross-lamination (characteristic of winnowing bottom currents), hence, they probably were deposited in quiet water. The presence of grading, flute casts, and load casts within the siltstones suggest episodes of rapid deposition.

Station I. A covered interval of $6 \mathrm{~m}$ obscures the contact between the alternately bedded siltstones and slates, and the overlying fine to medium-grained arenites. However, elsewhere in the area the contact is seen to be abrupt. At this point on Fales River, a continuous exposure of an 18-m thick quartz-arenite unit is found high on the east bank (Upper Major Quartzite, rig. ?). Structureless beds ( 30 to $50 \mathrm{~cm}$ thick) of fine-grained pink-weathering arenite comprise the lower $10 \mathrm{~m}$. Coarse to medium-grained arenites are interbedded with fine-grained arenites in the upper $8 \mathrm{~m}$. Small-scale and medium-scale crosslamination is common in coarse-grained laminae and beds. Wave-formed cross-lamination is associated with coarse-grained laminae that occur at the tops of beds which have wave ripples on their upper surfaces. They also occur in coarse-grained laminae that alternate with fine-grained parallel laminae. The fine-grained arenites commonly have sets of subparallel laminae with low-angle inclinations relative to bedding planes (sand-wave forms).

In the upper $5 \mathrm{~m}$, the arenite beds are relatively thick (50 to $100 \mathrm{~cm}$ ) and generally lenticular, in contrast to the laterally continuous beds from 10 to $50 \mathrm{~cm}$ thick below. A scour-and=fill structure is evident at the base of one of these beds. Several of the beds pinch out laterally. Such lenses and scour structures indicate the erosional and channelized nature of the beds, and in this respect contrast with the sheet-like beds below. The very flat, extensive upper surface of this unit can be traced $60 \mathrm{~m}$ into the woods. Curiously, the attitude of this plane differs from that of the beds below.

Stratigraphic relationships within the quartzarenite unit and with the underlying and overlying strata have an important bearing on reconstructions of the depositional setting. Both of the bounding black slates are graptolitic and lack currentformed bedforms, hence, they probably were deposited in quiet, sub-wave base conditions. In contrast, the appearance of fine- to medium-grained arenites on top of the black slate-siltstone strata marks a sudden change in the type of sediment introduced into the depositional site. This vertical transition is not considered to be a normal coarsening upvard succession resulting from simple pro-deltaic or shoreline progradation (Selley, 1970). This abrupt transition from fine-grained sediments to arenites is thought to have been a response to a transgressive pulse of the sea, as discussed above. The appearance of coarse sand, wave-formed features and lenticular beds in the upper $8 \mathrm{~m}$ of the arenites indicates later shoaling and deposition above wave base. The arenites are thought to be related to initial transgression of the sea (Fig. 6A), but 
significant landward erosion, a seaward spread of arenite deposition, and locally, shoaling of the sea floor presumably took place before a significant, regional increase in the water-depth occurred.

The evidence of erosion in the upper $5 \mathrm{~m}$ and the attitude of the upper bedding surface of the unit suggests erosion and planation at the top of the arenites in response to changes in submarine morphological equilibrium. These changes are judged to have been in response to increasing water depth and adjustments in the sea-floor profile as a result of erosion.

The rocks that overlie the arenite unit are not exposed here, but at other outcrops at nearby localities they are observed to be siltstones and silty shales.

Station $J$. The next outcrops upsection on Fales River are $21 \mathrm{~m}$ downstream and consist of black, fissile, graptolite-bearing shales of the Kentville Formation. These are silt-poor shales that probably were deposited in quiet water, presumably offshore and in deeper water than that in which the sediments of the uppermost White Rock Formation were deposited.

\section{References}

ANDREWS, J.T., 1975, Glacial systems: an approach to glaciers and their environments; Duxbury Press.

BERG, R.R., 1975, Depositional environment of upper cretaceous Sussex Sandstone, House Creek Field, Wyoming; Am. Assoc. Pet. Geol., Bull., v. 59, pp. 2099-2110.

BERRY, W.B. and BOUCOT, A.J., 1973, Glacio-eustatic control of Late Ordovician - Early Silurian platform sedimentation and faunal changes; Geol. Soc. Amer., Bull., v. 84, p. 275-284.

BEUF, S., BIJOU-DUVAL, E., CHARPAL, de O., ROGNON, P., GARIEL, O., et BENNECEF, A., 1971, Les Gres du Paleozoique Inferieur au Sahara. Sedimentation et discontinuities - Evolution structurale d'un cratan; Inst. Francais Petrole, Coll. Sci. et Tech. Petrole, ijo. 18, $464 \mathrm{p}$.

BLOOM, A.L., 1971, Glacial-eustatic and isostatic controls of sea level since the last glaciation, in Turikian, K.K. (ed.), The Late Cenozoic Glacial Ages; Yale Univ. Press, $606 \mathrm{p}$.

BRENNER, R.L. and DAVIES, D.K., 1974, Oxfordian sedimentation in the western interior United States; Am. Assoc. Pet. Geol., Eull., v. 58 , pp. $407-428$

ERIDGES, P.H., 1975, The transgression of a hard substrate shelf: the Llandovery (Lower Silurian) of the Welsh Borderland; Jour. Sed. Pet., v. 45, pp. 79-94.

BRUUN, P., 1962, Sea level rise as a cause of shore erosion. J. Waterways and Harbors
Division; Am. Soc. Civ. Eng. Proc., v. 88 , p. 117-130.

CROSBY, L.G., 1962, Nolfville Map area, Nova Scotia; Geol. Surv. Can., Mem. 325, 67 p.

FLINT, R.F., 1971, Glacial and Quaternary Geology; John Wiley and Sons, Inc., $500 \mathrm{p}$.

GOLDRING, R. and BRIDGES, P., 1973, Sublittoral sheet sandstones; Jour. Sed. Petrol, v. 43. o. $736-747$.

HARLAND, W.B., and HEROD, K.N., 1975, Glaciations through time, in Wright, A.E. and Moseley, F. (ed.) Ice Ages: Ancient and Modern;p. 189216.

MORNER, N.A., 1975, Eustatic amplitude variations and world glacial changes; Geology, v. 3, p. 109-110.

SANDERS, J.E. and KUMAR, K!., 1975, Evidence of shoreface retreat and in-place "drowning" during Holocene submergence of barriers, shelf off Fire Island, New York; Geol. Soc. Amer., Bull. v. 86, p. 65-76.

SCHENK, P.I., 1972, Possible Late Ordovician glaciation of Nova Scotia; Can. J. Earth Sci., v. 9 , p. 95-107.

SCHWARTZ, M.L., 1965, Laboratory study of sea level rise as a cuase of shore erosion; Jour. Geol., v. 73 , pp. 528-534.

SCHWARTZ, M.L., 1968, The scale of shore erosion: J. Geol., v. 76, p. 508-517.

SELLEY, R.C., 1971, Ancient sedimentary environments; Cornell University Press., Ithaca, N.Y., 240 p.

SPEARING, D.R., 1975, Shallow marine sands, in Harms, J.C., Southard, J.B., Spearing, D.R. and Walker, R.G., Depositional environments as interpreted from primary sedimentary structures and stratigraphic sequences; SEPM Short Course No. 2 , p. 103-132.

SMITHERINGALE, W.G., 1973, Geology of parts of Digby, Bridgetown, and Gaspereau Lake mapareas, Nova Scotia; Geol. Surv. Canada, Mem. $375,78 \mathrm{p}$.

TAYLOR, F.C., 1965, Silurian stratigraphy and Ordovician - Silurian relationships in southwestern Nova Scotia; Geol. Surv. Can., Paper 64-13.

TAYLOR, F.C., 1967, Reconnaissance geology of Shelburne and Yarmouth counties, Nova Scotia; Geol. Surv. Canada, Mem. 349, 83 p.

TAYLOR, F.C., 1969, Geology of the Annapolis - St. Mary's Bay map-area; Geol. Surv. Canada, Mem. $358,65 \mathrm{p}$.

TERMIER, H., et TERMIER, G., 1952, Histoire Geologique de les Biosphere, Masson, Paris. 